
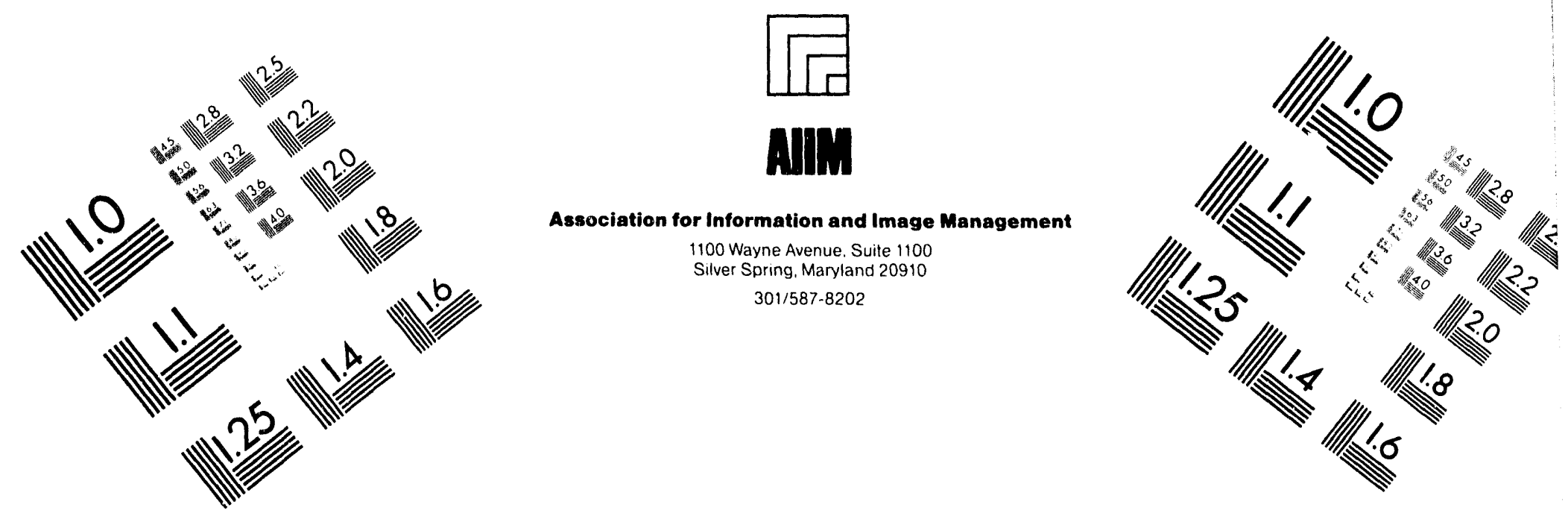

\title{
Centimeter
}

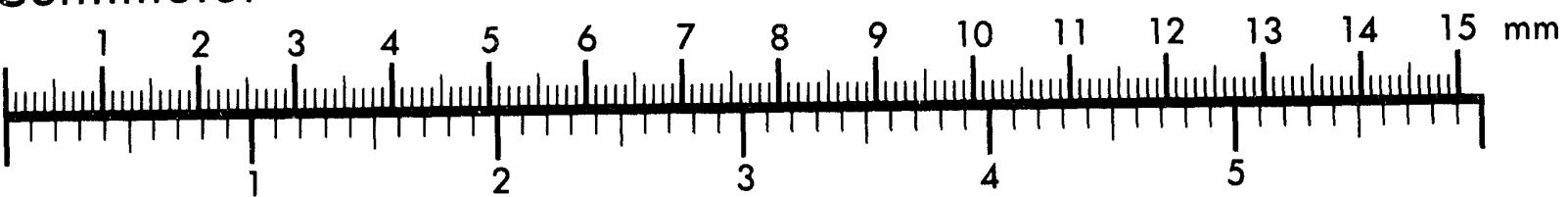
Inches
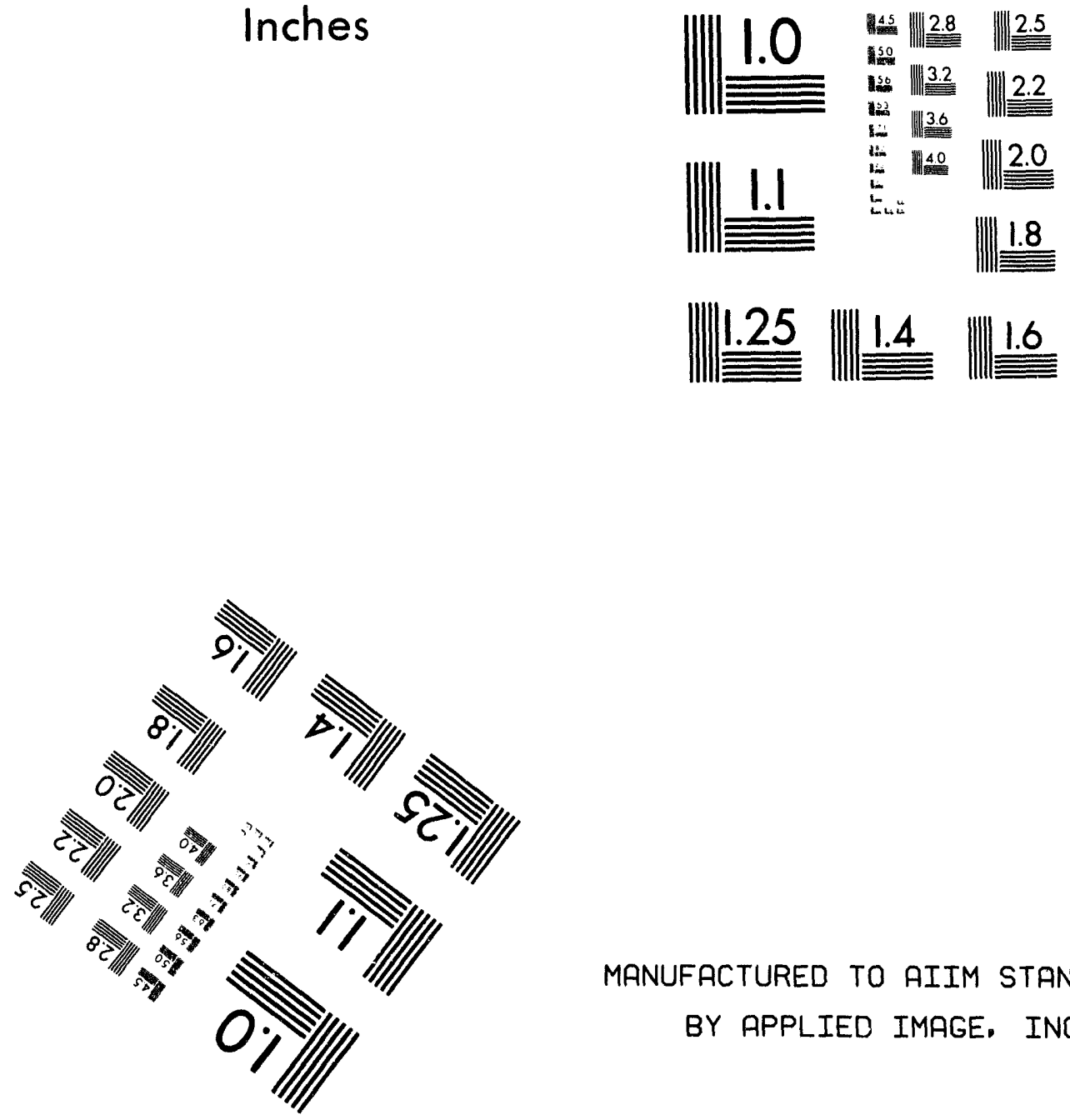

MANUFACTURED TO AIIM STANDARDS BY APPLIED IMAGE, INC.

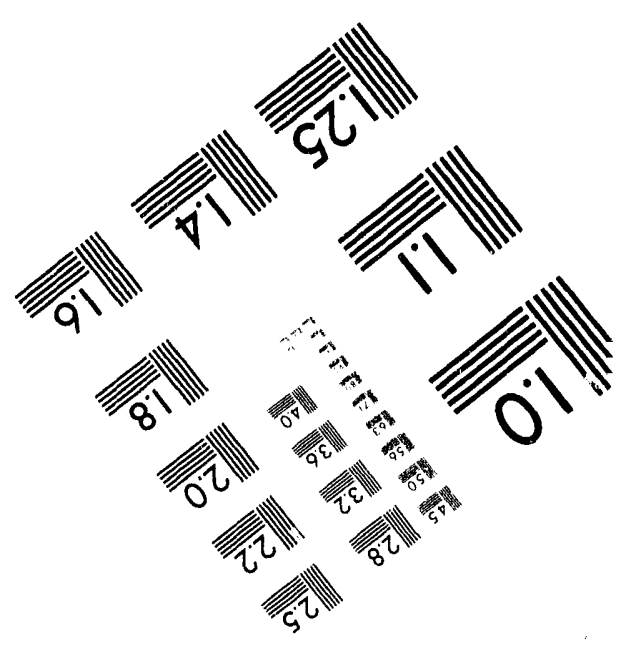



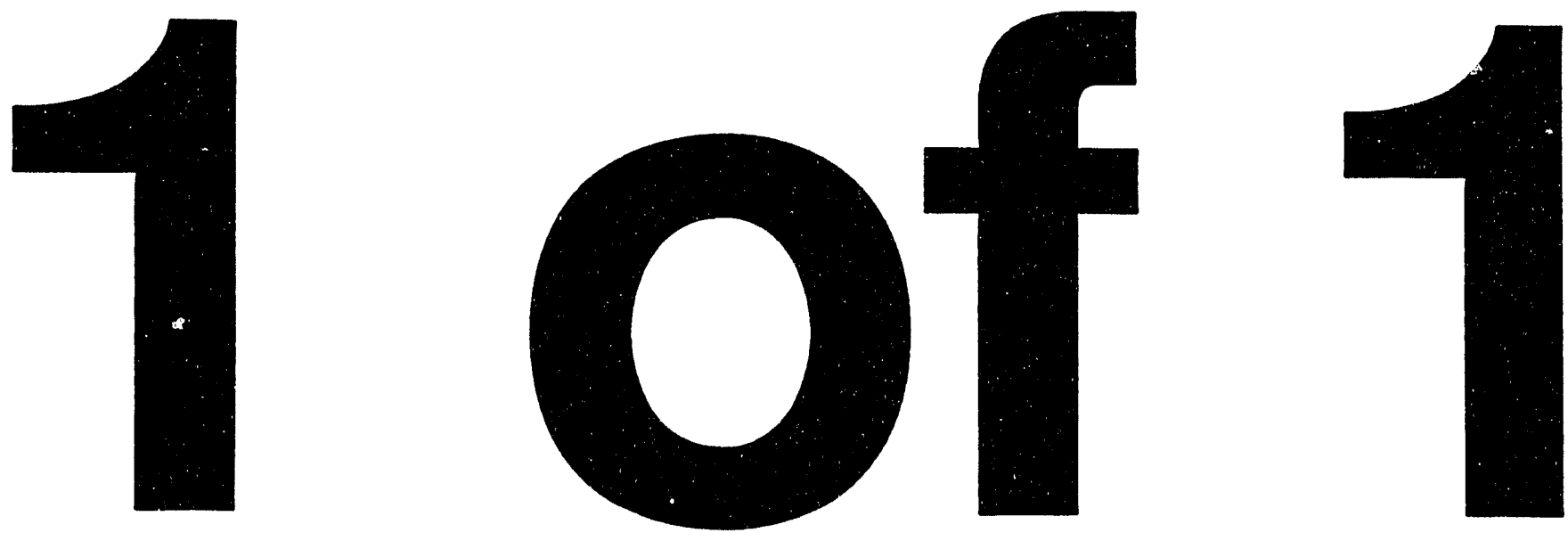
PNL-10088

UC-350

\section{Analysis of Heat Pumps Installed in Family Housing at Hunter Army Air Field}

S. A. Parker

August 1994

Prepared for

the U.S. Department of Energy

Federal Energy Management Program

under Contract DE-AC06-76RLO 1830

Pacific Northwest Laboratory

Richland, Washington 99352 


\begin{abstract}
The U.S. Army Forces Command (FORSCOM) tasked Pacific Northwest Laboratory (PNL)(a) in support of the U.S. Department of Energy (DOE) Federal Energy Management Program (FEMP) to conduct a postconstruction evaluation of the air-source heat pumps installed in family housing at Huntor Army Air Field (AAF). The objective of this project was to investigate and resolve concerns about an increase in energy costs at Hunter AAF following the installation of heat pumps in November 1992.
\end{abstract}

After completing several analyses and a field inspection of the heat pumps in family housing at Hunter AAF, the following conclusions were made:

- The installation of air-source heat pumps reduced the annual energy cost in family housing by $\$ 46,672$ in 1993 . There was no statistically significant impact on annual electricity consumption or billed demand for 1993 . Installing air-source heat pumps did not significantly change annual electric utility costs in 1993, but it did decrease fuel oil consumption by an estimated $66,674 \mathrm{gal}(9,334.4 \mathrm{MBtu})$ at a value of $\$ 46,672$.

- The heat pump thermostat controls in Hunter AAF family housing appear to be incorrectly installed. An inspection of a few units indicated that while the thermostat controls are in the heating mode, the resistance heaters are used as the primary heating source and the heat pump compressor does not operate simultaneously with the resistance heaters. Therefore, PNL recommends a qualified service technician trace the wiring from the thermostat controls to the heat pumps to ensure they are connected according to the manufacturer's specifications and correct if necessary. The cooling mode appears to be operating correctly.

- The Hunter AAF electric utility bill increased 10\% during the first 6 months of 1993 compared to the first 6 months of 1992. In December 1992, Savannah Electric and Power Company increased the fuel cost recovery component of the electric billing structure by $20 \%$. This increase accounted for $74 \%$ of the total increase in the electric utility costs at Hunter AAF. The rest of the cost increase (26\%) was because of an increase in energy consumption resulting from an increase in the electric heating load and cooling degree-days.

(a) Pacific Northwest Laboratory is operated by Battelle Memorial Institute for the U.S. Department of Energy under Contract DE-ACO6-7CRLO 1830. 


\section{Summary}

The U.S. Army Forces Command (FORSCOM) tasked Pacific Northwest Laboratory (PNL) in support of the U.S. Department of Energy (DOE) Federal Energy Management Program (FEMP) to conduct a postconstruction evaluation of the air-source heat pumps installed in family housing at Hunter Army Air Field (AAF). The objective of this project was to investigate and resolve concerns about an increase in energy costs at Hunter AAF following the installation of heat pumps.

The scope of this project encompassed six primary tasks: 1) determine a baseline energy consumption from actual metered data for the Hunter AAF family housing area, 2) determine the change in energy consumption resulting from the installation of heat pumps, 3) compare this change in energy consumption to the estimated consumption, 4) if the actual change in energy consumption differed from that estimated, then perform a utility cost analysis to identify the major causes for the difference, 5) verify if costs have increased at Hunter AAF, and 6) if costs have increased, identify to the extent possible, the causes for the cost increase.

After completing several analyses and a field inspection of the heat pumps in family housing at Hunter AAF, the following conclusions were made:

- The installation of air-source heat pumps reduced the annual energy cost in family housing by $\$ 46,672$ in 1993 . There was no statistically significant impact on annual electricity consumption or billed demand for 1993. Installing air-source heat pumps did not significantly change annual electric utility costs in 1993, but it did reduce fuel oil consumption by an estimated $66,674 \mathrm{gal}(9,334.4 \mathrm{MBtu})$ at a value of $\$ 46,672$.

- The heat pump thermostat controls in Hunter AAF family housing appear to be incorrectly installed. An inspection of a few units indicated that while the thermostat controls are in the heating mode, the resistance heaters are used as the primary heating source and the heat pump compressor does not operate simultaneously with the resistance heaters. Therefore, PNL recommends a qualified service technician trace the wiring from the thermostat controls to the heat pumps to ensure they are connected according to the manufacturer's specifications and correct if necessary. The cooling mode appears to be operating correctly.

- The Hunter AAF electric utility bill increased 10\% during the first 6 months of 1993 compared to the first 6 months of 1992. In December 1992, Savannah Electric and Power Company increased the fuel cost recovery component of the electric billing structure by $20 \%$. This increase accounted for $74 \%$ of the total increase in the electric utility costs at Hunter AAF. The rest of the cost increase (26\%) was because of an increase in energy consumption resulting from an increase in the electric heating load and cooling degree-days. 


\section{Contents}

Abstract $\ldots \ldots \ldots \ldots \ldots \ldots \ldots \ldots \ldots \ldots \ldots \ldots \ldots \ldots \ldots \ldots \ldots \ldots \ldots \ldots$

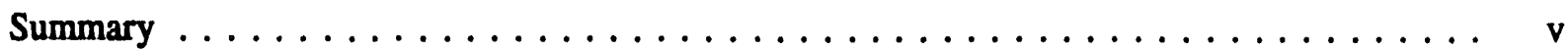

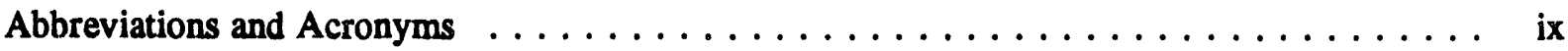

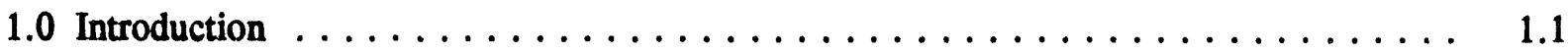

2.0 Determine Baseline Energy Consumption $\ldots \ldots \ldots \ldots \ldots \ldots \ldots \ldots \ldots \ldots$

2.1 Review Metered Energy Consumption Data $\ldots \ldots \ldots \ldots \ldots \ldots \ldots \ldots$

2.2 Identify Environmental, Mission, or Occupancy

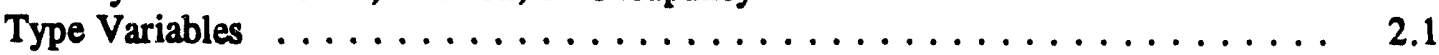

2.3 Correlate Climatological Data to Energy

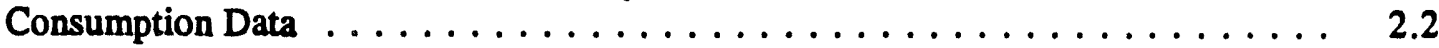

3.0 Determine Change in Energy Consumption Using Heat Pumps $\ldots \ldots \ldots \ldots \ldots \ldots$

4.0 Compare Expected Heat Pump Energy Consumption to Actual Consumption . . . . . . . 4.1

5.0 Perform Utility Cost Analysis $\ldots \ldots \ldots \ldots \ldots \ldots \ldots \ldots \ldots \ldots \ldots \ldots$

6.0 Verify and Identify Causes for Electricity Cost Increase $\ldots \ldots \ldots \ldots \ldots \ldots . \ldots$

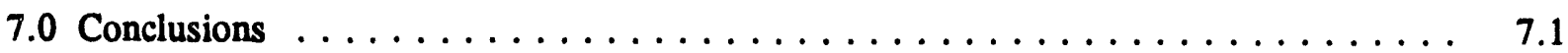

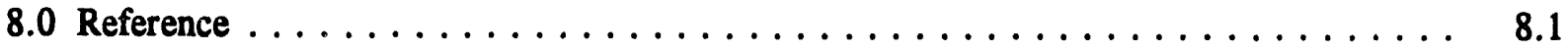

Appendix A - Electric Submeter and Weather Data, Hunter AAF Family Housing . . . . . . A.1

Appendix B - Fuel Oil Delivery and Weather Data, Hunter AAF Family Housing . . . . . . B.1

Appendix C - Monthly Regression Analysis Results, Hunter AAF Family Housing . . . . . C.1

Appendix D - 12-Month Floating Window Regression Analysis Results, Hunter AAF

Appendix E - Electric Utility Billing Data, Hunter AAF $\ldots \ldots \ldots \ldots \ldots \ldots$ E.1 


\section{Figures}

2.1 Local Climatological Data, Hunter AAF Family Housing $\ldots \ldots \ldots \ldots \ldots \ldots .2$

2.2 Weather Data Correlation, Hunter AAF Family Housing $\ldots \ldots \ldots \ldots \ldots \ldots \ldots$

2.3 Monthly Regression Model, Hunter AAF Family Housing $\ldots \ldots \ldots \ldots \ldots \ldots \ldots$

2.4 Local Climatological Data-12-Month Floating Window, Hunter AAF Family Housing . . . . . . . . . . . . . . . . . . . . . . 2.4

2.5 Weather Data Correlation-12-Month Floating Window, Hunter AAF

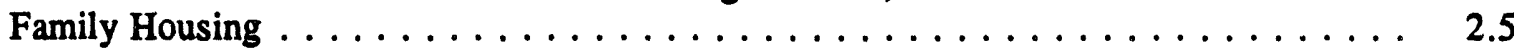

2.6 Regression Model-12-Month Floating Window, Hunter AAF Family Housing $\ldots \ldots \quad 2.5$

3.1 Monthly Regression Forecast, Hunter AAF Family Housing $\ldots \ldots \ldots \ldots \ldots \ldots$

3.2 Monthly Regression Confidence Interval, Hunter AAF Family Housing $\ldots \ldots \ldots \ldots$

3.3 Regression Forecast-12-Month Floating Window, Hunter AAF Family Housing . . . . 3.3

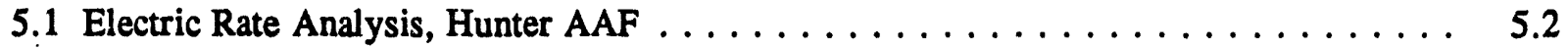

\section{Tables}

3.1 Monthly Regression Analysis Data for $1993 \ldots \ldots \ldots \ldots \ldots \ldots \ldots \ldots . \ldots \ldots$

5.1 Electric Service Rates for Hunter AAF $\ldots \ldots \ldots \ldots \ldots \ldots \ldots \ldots \ldots . \ldots \ldots$

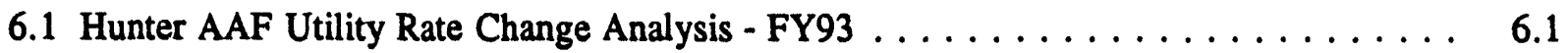




\section{Abbreviations and Acronyms}

$\begin{array}{ll}\text { AAF } & \text { Army Air Field } \\ \text { AFUE } & \text { annual fuel utilization efficiency } \\ \text { Btu } & \text { British thermal unit } \\ \text { Btu/h } & \text { British thermal unit per hour } \\ \text { CDD } & \text { cooling degree-day } \\ \text { COP } & \text { coefficient of performance } \\ \text { CR } & \text { cost recovery } \\ \text { DOE } & \text { U.S. Department of Energy } \\ \text { EER } & \text { energy efficiency ratio } \\ \text { FEMP } & \text { Federal Energy Management Program } \\ \text { FORSCOM } & \text { U.S. Army Forces Command } \\ \text { FY } & \text { fiscal year } \\ \text { HDD } & \text { heating degree-day } \\ \text { HSPF } & \text { heating seasonal performance factor } \\ \text { HVAC } & \text { heating, ventilating, and air conditioning } \\ \text { KW } & \text { kilowatt } \\ \text { kWh } & \text { kilowatt per hour } \\ \text { LCC } & \text { life-cycle cost } \\ \text { MBtu } & \text { million British thermal units } \\ \text { NCO } & \text { noncommissioned officer } \\ \text { PNL } & \text { Pacific Northwest Laboratory } \\ \text { SEER } & \text { seasonal energy efficiency ratio }\end{array}$




\subsection{Introduction}

Prior to installing air-source heat pumps, family housing at Hunter Army Air Field (AAF) was heated by fuel oil furnaces and cooled by electric direct-expansion air conditioners. Domestic hot water was provided by electric water heaters. Hunter AAF originally contracted to have the fuel oil furnaces replaced with natural gas furnaces. However, an alternative proposal was made to install airsource heat pumps to provide space conditioning in family housing. An analysis was performed by B. B. Wise \& Associates (Billy Wise) on behalf of Savannah Electric and Power Company, the local electric utility. Pacific Northwest Laboratory (PNL) reviewed the Billy Wise report ${ }^{(a)}$ on the analysis and evaluated the life-cycle costs (LCCs) of the heating, ventilating, and air-conditioning (HVAC) upgrade alternatives to determine the most cost-effective source of space conditioning for family housing. The result of the analysis was that the air-source heat pump alternative had a lower LCC than the natural gas furnace alternative. This conclusion was provided to Mr. Adrian Gillespie, U.S. Army Forces Command (FORSCOM), in a letter dated November 8, 1991. ${ }^{(b)}$ The installation of the heat pumps began in August 1992 and was completed in November 1992.

The U.S. Army FORSCOM tasked PNL in support of the U.S. Department of Energy (DOE) Federal Energy Management Program (FEMP) to conduct a postconstruction evaluation of the air-source heat pumps installed in family housing at Hunter AAF. The objective of this project was to investigate and resolve concerns about an increase in energy costs at Hunter AAF following the installation of heat pumps.

The scope of this project encompassed six primary tasks: 1) determine a baseline energy consumption from actual metered data for the Hunter AAF family housing area, 2) determine the change in energy consumption resulting from the installation of heat pumps, 3) compare this change in energy consumption to the estimated consumption, 4) if the actual change in energy consumption differed from that estimated, then perform a utility cost analysis to identify the major causes for the difference, 5) verify if energy costs have increased at Hunter AAF, and 6) if costs have increased, identify to the extent possible, the causes for the increase.

In Sections 2.0 through 6.0 of this report, the following project tasks are discussed, respectively: determine a baseline energy consumption for the Hunter AAF family housing area, determine the change in energy consumption using heat pumps, compare the actual heat pump energy consumption to the estimated consumption, perform a utility cost analysis, and verify and identify the major causes for the energy cost increase. Section 7.0 provides conclusions for the evaluation of air-source heat pumps installed in family housing. Appendix A shows electric submeter and weather data, Appendix B shows fuel oil delivery and weather data, Appendix $C$ shows the monthly regression analysis results,

(a) 1991 letter report, B. B. Wise \& Associates, Dunwoody, Georgia.

(b) 1991 letter from PNL to Adrian Gillespie, U.S. Army FORSCOM, Fort McPherson, Georgia. 
Appendix D shows the 12-month floating window regression analysis results, and Appendix $\mathrm{E}$ shows electric utility billing data for family housing at Hunter AAF. 


\subsection{Determine Baseline Energy Consumption}

The first task in this analysis was to determine a baseline energy consumption for the family housing area at Hunter AAF. As part of this task, PNL 1) reviewed the metered energy consumption data for family housing, including electricity and fuel oil, 2) identified, and correlated if necessary, any environmental, mission, or occupancy type variables that could impact the analysis, and 3) correlated local climatological data to the energy consumption data. Once this information was assimilated, a baseline model for energy consumption could be developed for family housing.

\subsection{Review Metered Energy Consumption Data}

A single electric utility meter, read by Savannah Electric and Power Company, monitors electricity consumption and peak demand at Hunter AAF. In addition, Hunter AAF operates a few electric submeters for specific divisions. These submeters include electricity consumption, but do not include demand information. The commissioned and noncommissioned officer (NCO) family housing areas are served with individual electric submeters. These submeters monitor total electricity consumption for each housing area, including HVAC systems, domestic hot water, lighting, laundry, cooking, refrigeration, and other miscellaneous end uses. The electric submeters are manually read during the middle of each month. The various submeters are usually read on the same day, although there are exceptions. Electricity consumption records, which are kept at Hunter AAF, indicate each meter reading and the date the meter was read. Because the meter readings are dated, electricity consumption can be synchronized with local weather data. Electric submeter and weather data for family housing are shown in Appendix A.

Fuel oil served only the previous furnace heating systems in the family housing at Hunter AAF. While this would make fuel oil consumption relative to weather data, fuel oil delivery does not always correlate with fuel oil consumption. The fuel oil records are much more complicated to analyze than the electric records. There were several fuel oil tanks throughout the two main housing areas before they were removed as part of the heat pump installation. These tanks were refueled on an irregular basis and recorded in log books. Fuel oil tanks were refueled between two to five times each year, but not always at the same time. Furthermore, because of the number of fuel oil tanks, not all tanks were refueled during the same months. Fuel oil records, which are kept at Hunter AAF, indicate the total fuel oil delivered during each month. Although the fuel oil records break down deliveries into major divisions at Hunter AAF (one division being family housing), they do not indicate which tanks were refueled or what day they were refueled. This level of detail would require reconciling individual fuel oil tank log books. Therefore, it is difficult to relate fuel consumption to local weather data except on a gross annualized basis. The fuel oil delivery and weather data are shown in Appendix B.

\subsection{Identify Environmental, Mission, or Occupancy Type Variables}

Energy consumption for family housing should vary based on 1) the number of days in the billing (consumption) period, 2) local climatological (weather) data, 3) occupancy factors, and 4) other 
environmental or mission-related variables. Communications with personnel at Hunter AAF by PNL staff did not identify any notable changes in housing occupancy rates or other environmental or mission-related variables during the past 3 years that would account for a significant variation in energy consumption in the family housing areas. Therefore, the baseline analysis was limited to the first two major factors-consumption period and weather data.

\subsection{Correlate Climatological Data to Energy Consumption Data}

Because weather is the most notable variable in this analysis, local climatological data were obtained from the National Oceanic and Atmospheric Administration's National Climatic Data Center for Savannah, Georgia. Monthly summary reports, which inciuded summarized daily weather data, were obtained for the period January 1991 through January 1994, inclusive.

Weather data, in the form of cooling degree-days (CDDs) and heating degree-days (HDDs) (base $65^{\circ} \mathrm{F}$ ), are synchronized with monthly metering periods and listed in Appendix A with the corresponding electricity consumption data. Because fuel oil consumption can be assumed only from annual fuel oil delivery on a gross annual basis, heating degree-days are similarly summarized in Appendix B. These monthly weather (climatological) data are also illustrated in Figure 2.1.

As illustrated in Figure 2.2, cooling degree-days appear to have a high correlation to monthly electricity consumption. Several multivariate linear regression analyses were performed on the monthly metering and weather data. The output from the most conclusive analysis is shown in Appendix C.

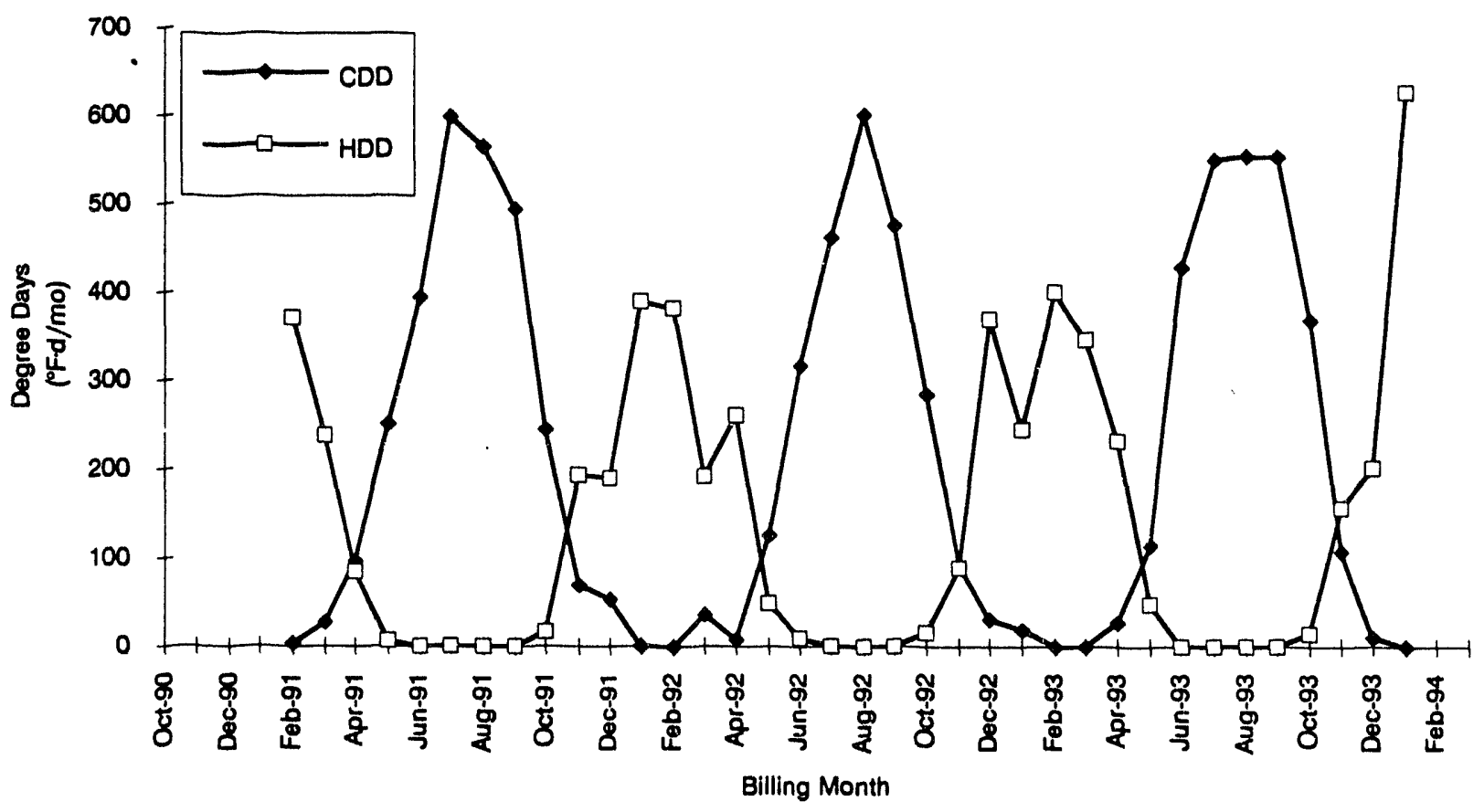

Figure 2.1. Local Climatological Data, Hunter AAF Family Housing 


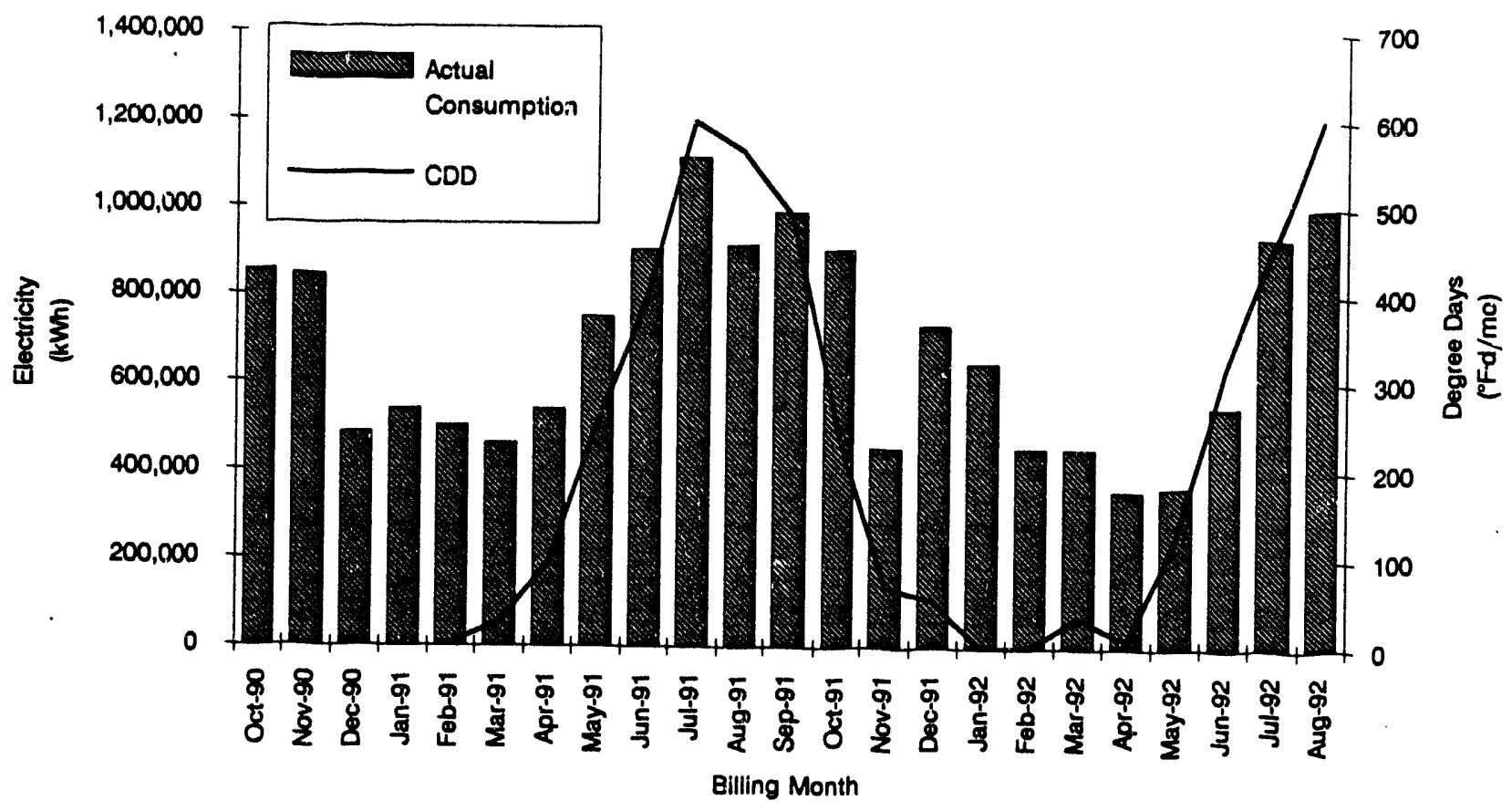

Figure 2.2. Weather Data Correlation, Hunter AAF Family Housing

The result of the monthly analysis is illustrated in Figure 2.3. As shown, the regression is a good fit, but has a wide confidence interval. This interval is partly because of the limited number of data points and natutal variation, but may also be an indication of the existence of other, unaccountable variables.

Because the monthly analysis has significant variations, further compounded within seasonal variations, a separate analysis was performed using a 12-month floating window. A 12-month floating window analysis examines annual data points (12-month totals) with the next data point offset by only one month. For example, the September 1991 data point includes the total for the October 1990 through September 1991 window, inclusive. The next data point, October 1991, includes the next annual total offset by one month for the November 1990 through October 1991 window, inclusive. This technique has a smoothing effect because each data point incorporates a full year and all seasons.

Weather (climatological) data, in the form of annual heating and cooling degree-days and corresponding to the 12-month floating window, are illustrated in Figure 2.4. As shown, there has been some change in the magnitude of the heating and cooling seasons since 1991. Cooling degree-days notably dropped in 1992 from 1991 and then partially increased in 1993. This drop was reflected in the family housing electricity consumption as illustrated in Figure 2.5. A linear regression analysis performed on the floating window metering and weather data shows a very good fit. The output from the analysis is shown in Appendix D. The result of the floating window analysis is illustrated in Figure 2.6. The regression is very smooth, but has a wide confidence interval. This interval is primarily because of the very limited number of data points. 


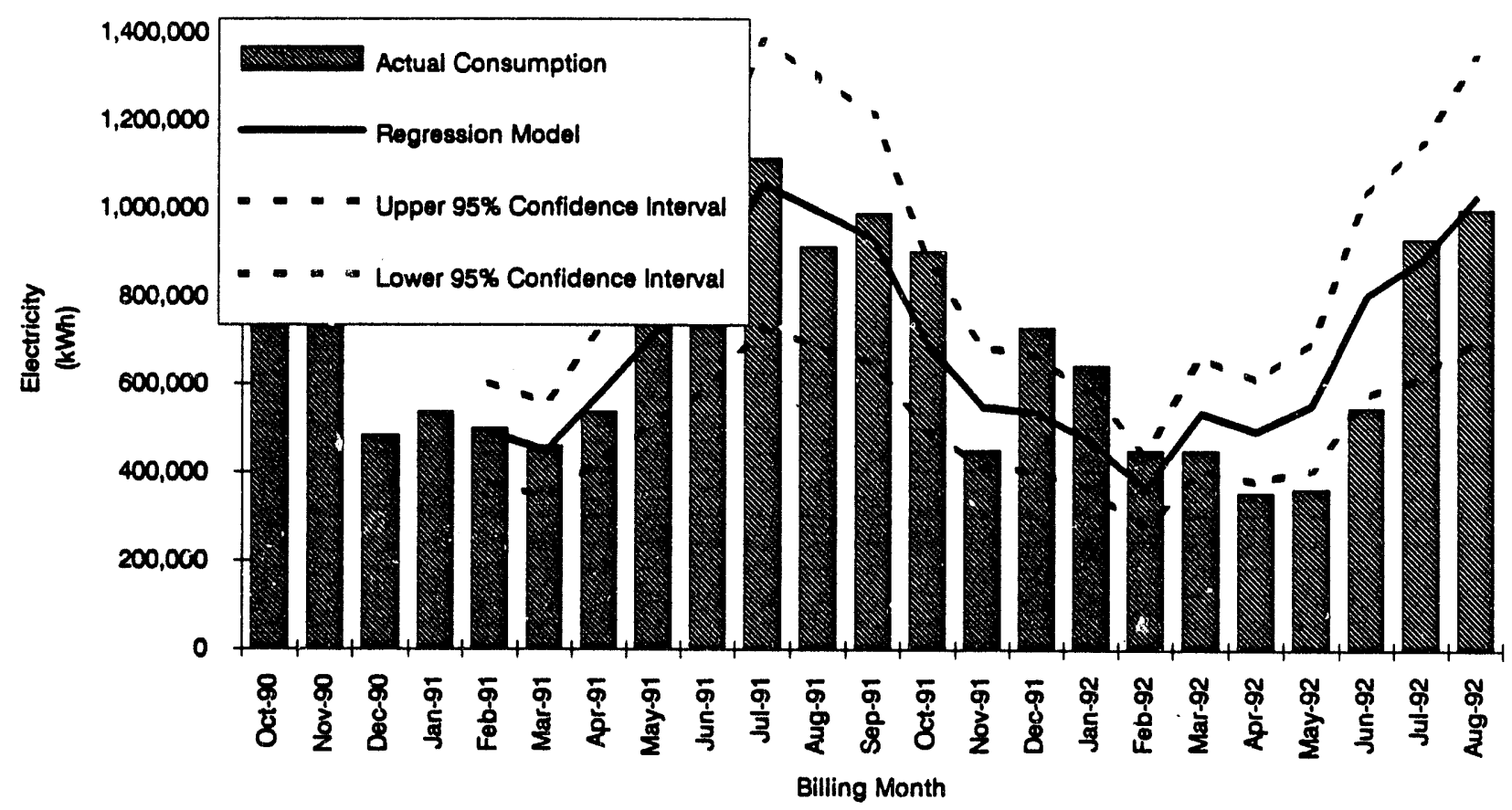

Figure 2.3. Monthly Regression Model, Hunter AAF Farnily Hut sing

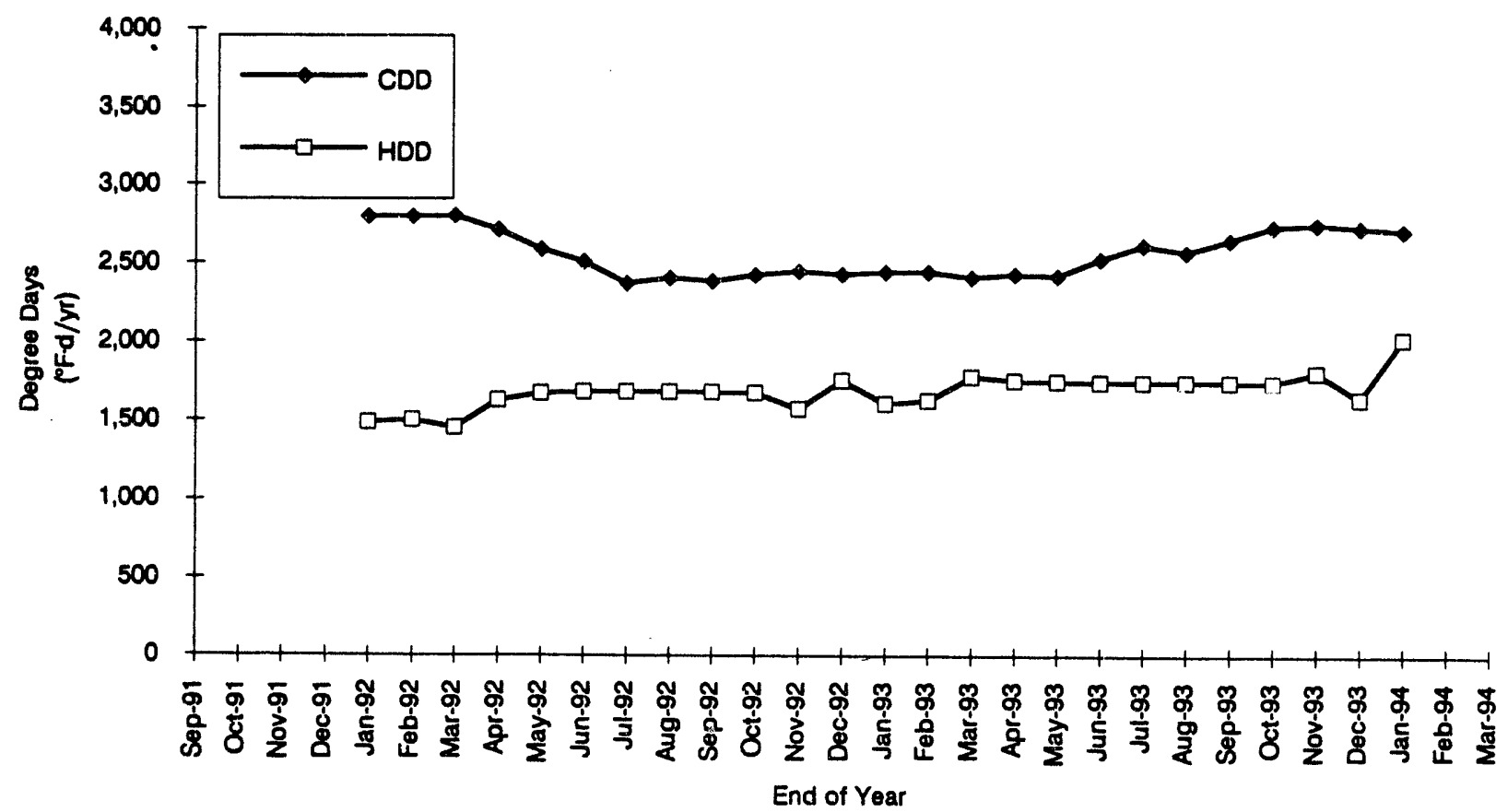

Figure 2.4. Local Climatological Data-12-Month Floating Window, Hunter AAF Family i!ousing 


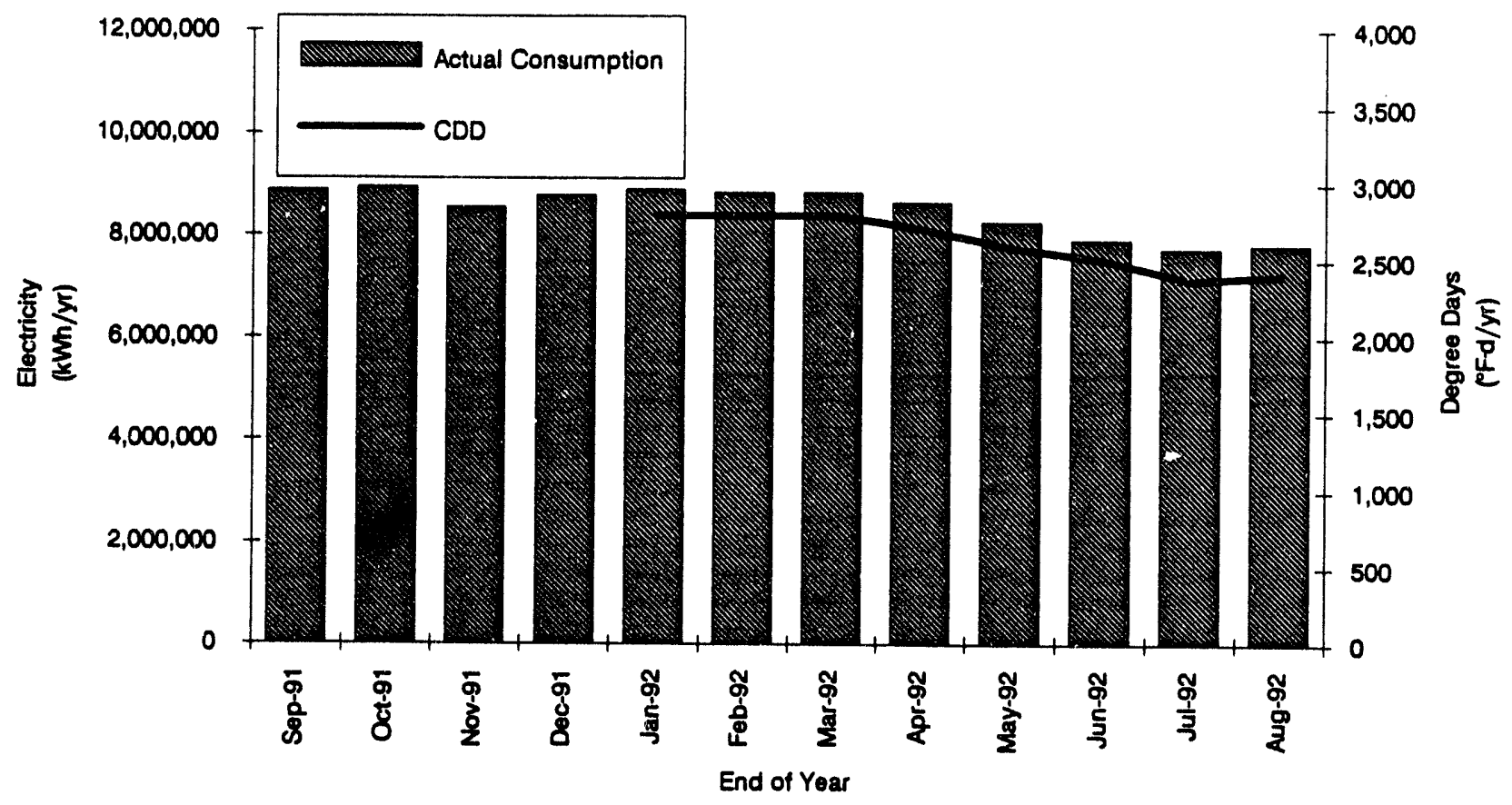

Figure 2.5. Weather Data Correlation-12-Month Floating Window, Hunter AAF Family Housing

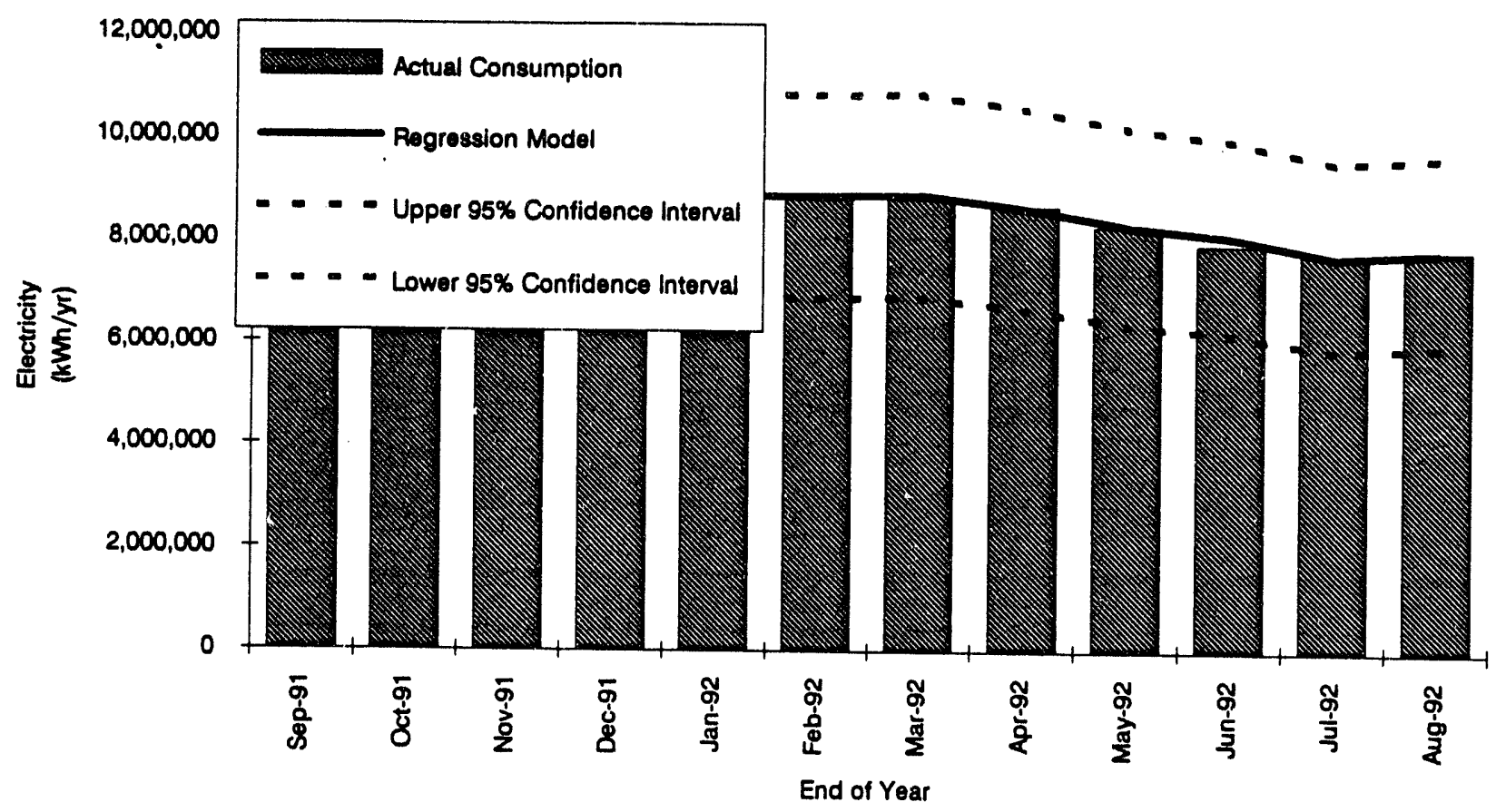

Figure 2.6. Regression Model-12-Month Floating Window, Hunter AAF Family Housing 


\subsection{Determine Change in Energy Consumption Using Heat Pumps}

Using the monthly regression model, Figure 3.1 illustrates a forecast of electricity consumption for family housing. The forecast compares electricity consumption using previous direct-expansion airconditioning systems to actual electricity consumption using heat pumps. As illustrated, electricity consumption increased in the heating season because electricity is now being used for heating instead of fuel oil. The figure also illustrates a notable reduction in electricity consumption during the cooling season because of the increase in cooling efficiency.

The data illustrated in Figure 3.1 for calendar year 1993 are identified in Table 3.1. The data indicate that electricity consumption increased during the off-peak electric period, October through May, and decreased during the on-peak electric period, June through September, for a net increase in electricity consurnption of 266,926 kWh/yr. Using the Savannah Electric and Power Company incremental electricity rates $^{(\mathbf{a})}$ for 1993 , this net increase equates to an increase of $\$ 7,490$ in the annual electricity cost for 1993.

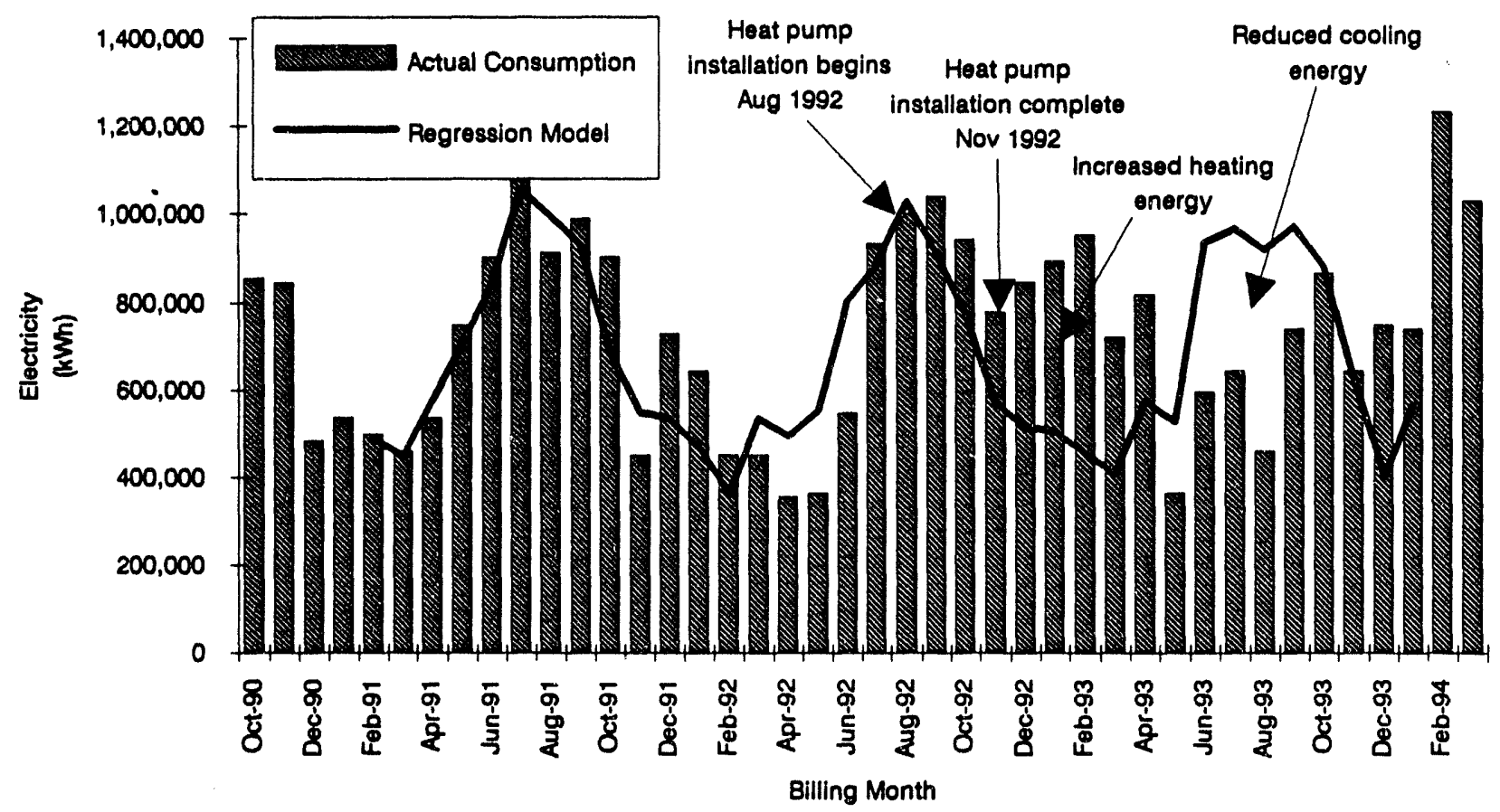

Figure 3.1. Monthly Regression Forecast, Hunter AAF Family Housing

(a) For more information on the incremental electricity rate, see Section 5.0. 
Table 3.1. Monthly Regression Analysis Data for 1993

\begin{tabular}{|c|c|c|c|c|}
\hline $\begin{array}{l}\text { Billing } \\
\text { Month }\end{array}$ & Period & $\begin{array}{c}\text { Actual } \\
\text { Consumption } \\
(\mathrm{kWh})\end{array}$ & $\begin{array}{c}\text { Regression } \\
\text { Estimate } \\
(\mathrm{kWh})\end{array}$ & $\begin{array}{c}\text { Difference } \\
(\mathrm{kWh})\end{array}$ \\
\hline Jan & Off-Peak & 892,800 & 504,829 & 387,971 \\
\hline Feb & Off-Peak & 950,400 & 456,338 & 494,062 \\
\hline Mar & Off-Peak & 720,000 & 409,130 & 310,870 \\
\hline Apr & Off-Peak & 816,000 & 574,938 & 241,062 \\
\hline May & Off-Peak & 364,800 & 527,879 & $(163,079)$ \\
\hline Jun & On-Peak & 595,200 & 933,245 & $(338,045)$ \\
\hline Jul & On-Peak & 643,200 & 963,849 & $(320,649)$ \\
\hline Aug & On-Peak & 460,800 & 918,312 & $(457,512)$ \\
\hline Sep & On-Peak & 739,200 & 968,449 & $(229,249)$ \\
\hline Oct & Off-Peak & 864,000 & 880,394 & $(16,394)$ \\
\hline Nov & Off-Peak & 643,200 & 631,759 & 11,441 \\
\hline Dec & Off-Peak & 748,800 & 402,352 & 346,448 \\
\hline Total & On-Peak & $2,438,400$ & $3,783,855$ & $(1,345,455)$ \\
\hline Tutal & Off-Peak & $6,000,000$ & $4,387,619$ & $1,612,381$ \\
\hline Total & Both & $8,438,400$ & $8,171,474$ & 266,926 \\
\hline
\end{tabular}

The monthly regression analysis has a high variance. Much of the change in electricity consumption from that forecasted by the regression model is not statistically significant. Figure 3.2 illustrates the regression forecast with the $95 \%$ confidence interval against actual electricity consumption for family housing. When viewing only electricity consumption beyond the $95 \%$ confidence interval as significant, electricity consumption increased substantially during the winter heating season and then decreased moderately during the summer cooling season for a net annual increase. The increase during the heating season is anticipated because electricity is being used for heating in addition to the base electric load. However, the decrease during the cooling season is not as recognizable partly because of the wide confidence interval during the summer cooling season. The heat pumps are responsible for an increase in cooling efficiency in the summer, but the increase in efficiency is not as significant as the additional heating load during the winter.

Using the floating window regression model, Figure 3.3 illustrates a comparison of forecasted electricity consumption for family housing using the previous direct-expansion air-conditioning systems with the actual electricity consumption in family housing using the heat pumps. As illustrated, electricity consumption increases during the FY93 heating season because electricity is being used for heating instead of fuel oil. Remembering that each bar in Figure 3.3 represents electricity consumption for a full year, if the heat pump cooling efficiency remained the same as the previous direct-expansion air- 


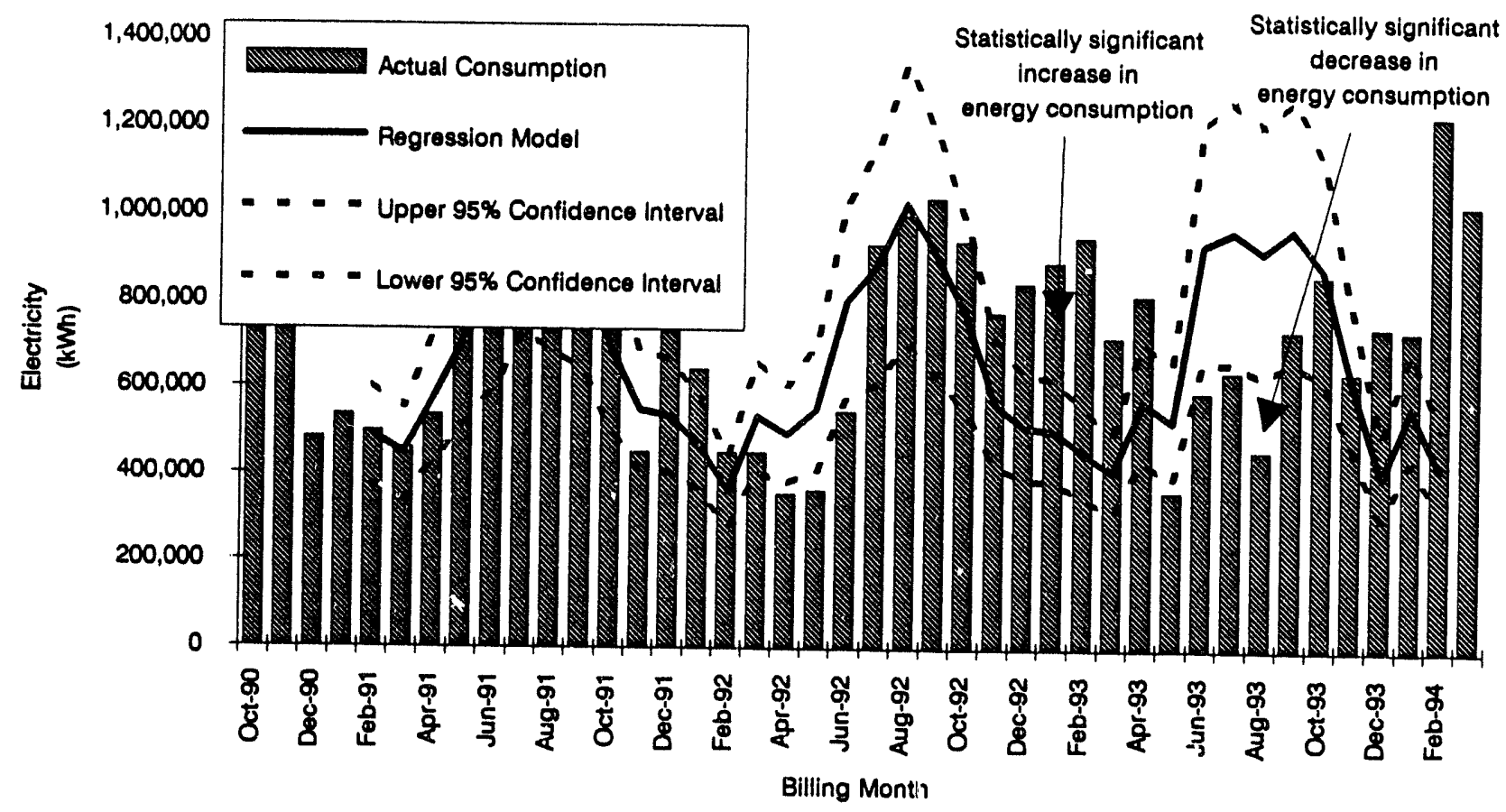

Figure 3.2. Monthly Regression Confidence Interval, Hunter AAF Family Housing

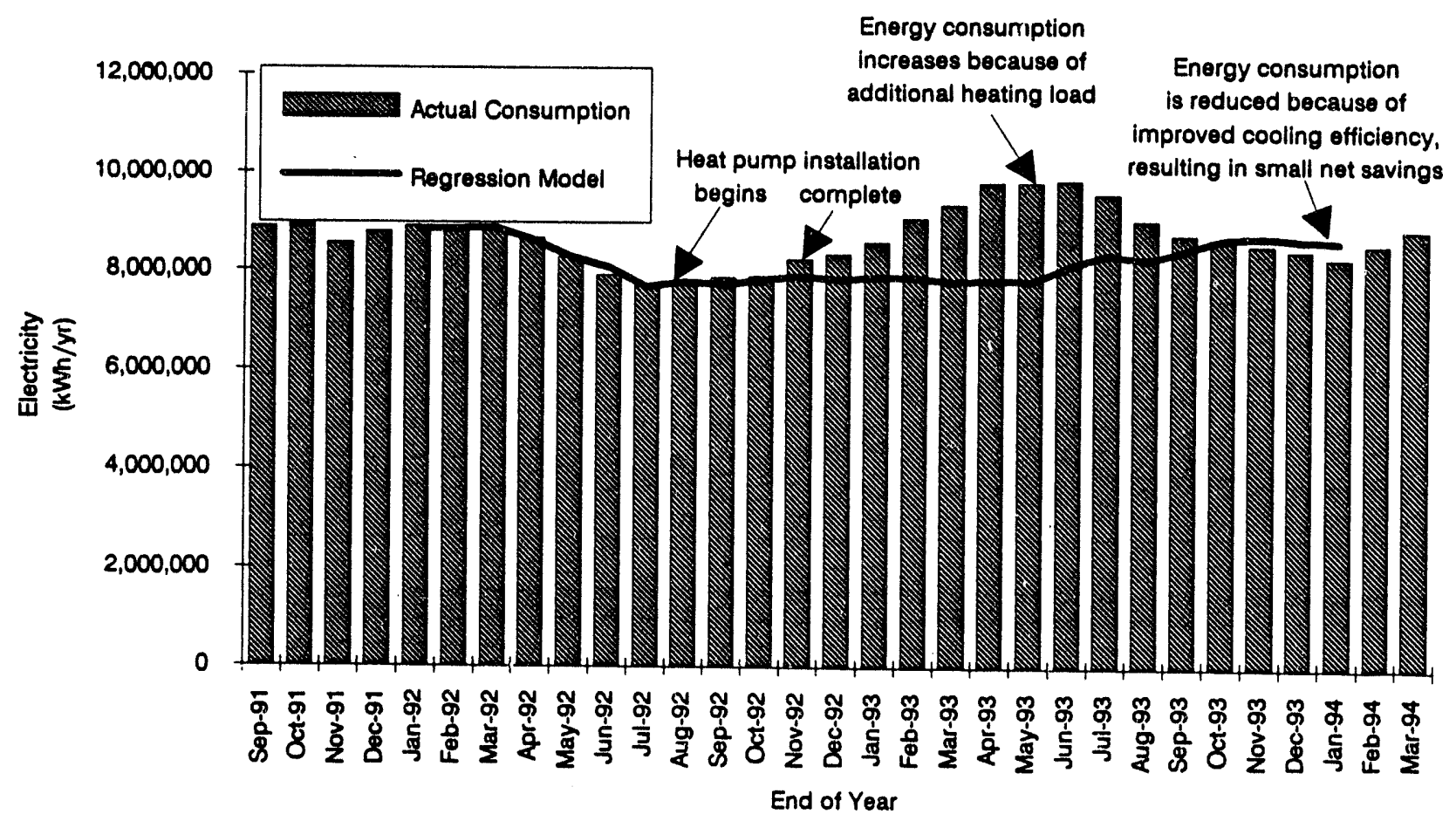

Figure 3.3. Regression Forecast-12-Month Floating Window, Hunter AAF Family Housing 
conditioning units, then electricity consumption would have remained above the regression model forecast line by an amount similar to that identified in May 1993 (approximate end of the heating season). However, because the cooling efficiency of the new heat pumps is higher than the previous directexpansion air-conditioning units, a drop in electricity consumption is illustrated through the summer of 1993.

By the end of 1993, actual electricity consumption was reduced so that annual electricity consumption using heat pumps providing both heating and cooling was actually somewhat less than (the forecast of) electricity consumption using the previous HVAC units that only provided cooling. However, the identified saving is within the confidence interval and therefore cannot be considered statistically significant.

The data illustrated in Figure 3.3 for 1993 indicate that actual electricity consumption increased significantly over the forecasted estimate during the heating season. Unfortunately, the 1993 heating season was not limited to only heat pumps. Heat pump installation was not complete until the end of November 1992. Furthermore, annual electricity consumption decreased significantly during the cooling season. Although interpreting the seasonal interaction during the changeover period from the HVAC system to the heat pumps may be misleading in a 12-month floating window analysis, the final result is usually more accurate than the monthly analysis performed earlier. The result in electricity consumption is a net decrease in electricity consumption of around $224,100 \mathrm{kWh} / \mathrm{yr}$. Using an average 1993 monthly incremental energy rate $(\$ 0.0334 / \mathrm{kWh})$, this net decrease equates to a decrease of $\$ 7,485$ in the annual electricity cost for 1993 .

As noted earlier, the 12-month floating window regression model has a wide confidence interval because of the limited sample size used in the model's development. Therefore, like the monthly regression analysis, the change in annual electricity consumption from that forecasted by the 12-month floating window regression analysis is not statistically significant.

According to the local climatological data for Savannah, Georgia, the heating season at Hunter AAF usually runs from October through May. Appendix B identifies fuel oil records for family housing and the heating degree-days, assuming full calendar months. Assumed delivery records over the 2year period FY91 through FY92 can be used to approximate consumption. Average fuel oil consumption for family housing is estimated to be $37.0 \mathrm{gal} / \mathrm{HDD}$.

The heat pump installation was completed in November 1992. Because the heating season at Hunter AAF runs from October through May, the heat pumps have not been used for a complete heating season as of the date of this analysis. When using calendar year 1993 (January 1, 1993 through December 31, 1993-not the electric billing months noted earlier) as the first year of heat pump operation, heating degree-days totaled $1,802^{\circ} \mathrm{F} / \mathrm{d} \mathrm{yr}$. Therefore, fuel oil consumption is estimated to have been approximately $66,674 \mathrm{gal}(9,334.4 \mathrm{MBtu})$ for 1993 . Using the fuel oil cost of $\$ 0.70 / \mathrm{gal}$, this amount of fuel oil consumption equates to an annual savings of $\$ 46,672$. 


\subsection{Compare Expected Heat Pump Energy Consumption' to Actual Consumption}

Comparing actual heat pump energy consumption to that of the previous direct-expansion airconditioning units and the fuel oil-fired furnaces from the original Billy Wise report $t^{(a)}$ and subsequent PNL life-cycle cost analysis report ${ }^{(b)}$ was not originally included in the scope of this study. However, a question arose on whether the heat pumps were performing up to expectations. The original reports did not study fuel oil as an option-only natural gas. However, because the efficiency of the natural gas option is in line with the expectation of the previous fuel oil furnaces (an annual fuel utilization efficiency [AFUE] of $75 \%$ ), a fuel oil equivalent was used for the comparison. The results of this comparison are summarized below.

- Three sizes of Payne heat pumps were installed at Hunter AAF-24,000 Btu/h, 30,000 Btu/h, and $36,000 \mathrm{Btu} / \mathrm{h}$, based on nominal cooling capacity. These sizes match the assumptions in the Billy Wise report. ${ }^{(a)}$ Each heat pump system also includes an $7.5 \mathrm{~kW}$ resistance heating coil for supplemental heat. According to the U.S. Army Corps of Engineers-Savannah office, 482 heat pumps were installed. The original Billy Wise report ${ }^{(a)}$ identified 477 units and $8.0 \mathrm{~kW}$ coils.

- The installed heat pumps are rated with a cooling seasonal energy efficiency ratio (SEER) of 10.0 Btu/W.h. They are also rated with a heating seasonal performance factor (HSPF) between 7.2 and $7.5 \mathrm{Btu} / \mathrm{W} \cdot \mathrm{h}$ (depending on the unit size), which equates to a seasonal coefficient of performance (COP) of 2.11 to 2.20 . The heating efficiency rated at $47^{\circ} \mathrm{F}$ is a COP of 3.08 to 3.14. The heating efficiency rated at $17^{\circ} \mathrm{F}$ is a COP of 2.22 to 2.32 . The Billy Wise report $^{(a)}$ identified a cooling energy efficiency ratio (EER) of $10.0 \mathrm{Btu} / \mathrm{W} \cdot \mathrm{h}$ and a heating efficiency COP of 3.0. The report did not identify the heating efficiency as a seasonal average or a specific temperature rating, nor can it be conciuded that the EER was not used as a SEER.

- Electricity consumption in family housing was estimated in the Billy Wise report ${ }^{(a)}$ to increase $1,283,115 \mathrm{kWh} / \mathrm{yr}$ using the heat pumps over that consumed using the air-conditioning units. In addition, fuel oil consumption in family housing was estimated to be reduced by $22,189.8 \mathrm{MBtu} / \mathrm{yr}(158,499 \mathrm{gal} / \mathrm{yr}$ equivalent) using the heat pumps. Because fuel oil consumption in family housing was only $51,286 \mathrm{gal}$ in FY91 and 58,466 gal in FY92, this expectation should have been identified as unrealistic. Furthermore, this estimate should have indicated the computer modeling used to estimate electricity consumption was similarly flawed.

(a) 1991 letter report, B. B. Wise \& Associates, Dunwoody, Georgia.

(b) 1991 letter from PNL to Adrian Gillespie, U.S. Army FORSCOM, Fort McPherson, Georgia. 
- There is an indication that the heat pump thermostat controls are incorrectly installed in family housing. Inspections of five units at Hunter AAF indicated that the resistance heaters, in the heating mode, are used as the primary heating source and the heat pump compressors do not operate simultaneously with the resistance heaters. An improved control strategy would operate the compressor when heating is first required. If the compressor is unable to satisfy the heating requirement, then the thermostat would activate the first, and if necessary the second, stage of the resistance heating. The compressor would continue to operate simultaneously with the resistance heating coils. The cooling mode appears to be operating correctly.

- The electricity rate used in the Billy Wise report ${ }^{(a)}$ and in the PNL LCC analysis ${ }^{(b)}$ was $\$ 0.03 / \mathrm{kWh}$. This rate was accurate during FY92. The PNL LCC analysis reported that the National Institute of Standards and Technology (NIST) LCC analysis electric rate escalation factors top out at $15 \%$ above the current price, meaning that Hunter AAF would be paying less than $\$ 0.035 / \mathrm{kWh}$ for 25 years in the future (NIST 1991). During the month following the completion of the heat pump installation (December 1992), Savannah Power and Electric Company raised the incremental cost of electricity to $\$ 0.0341 / \mathrm{kWh}-\mathrm{a} 12.2 \%$ cost increase over the $\$ 0.0304 / \mathrm{kWh}$ FY92 rate.

(a) 1991 letter report, B. B. Wise \& Associates, Dunwoody, Georgia.

(b) 1991 letter from PNL to Adrian Gillespie, U.S. Army FORSCOM, Fort McPherson, Georgia. 


\subsection{Perform Utility Cost Analysis}

This report also addresses a concern raised at Fort Stewart that total energy costs at Hunter AAF increased after the heat pumps were installed in family housing. To address this concern, and because a consumption iucrease is not indicated in the analysis in Section 3.0, PNL performed a similar analysis using the main electric billing data for Hunter AAF.

Savannah Power and Electric Company charges customers for electricity (energy), demand, excess reactive power (low power factor), fuel cost recovery (an energy charge based on the utility cost of fuel), and a basic facility (customer) charge. The energy charge is a five-step declining block schedule, meaning the unit cost of electricity decreases with additional consumption through five steps referred to as blocks. The demand charge is subject to a ratchet clause, meaning the billed demand for the month is the maximum of either the actual peak demand for the month or $70 \%$ of the largest peak demand established during any on-peak period of the immediately preceding 11 months. Peak demand is based on a 30-minute demand window. The off-peak billing season is October through May, inclusive, and the on-peak billing season is June through September, inclusive. Basic energy and demand charges are slightly higher during the on-peak billing season. A summary of the Hunter AAF electric utility billing data is shown in Appendix E.

Several regression analyses were performed using the Hunter AAF utility billing information for FY91 through FY93. The results of the analyses indicated conclusions similar to the conclusions from the analysis discussed in Section 3.0. However, because electricity consumption for family housing is only $18 \%$ of the total electricity consumption at Hunter AAF, the results are much less significant. The analyses results indicated that installing heat pumps in family housing at Hunter AAF did not have a significant impact on billed demand. Billed demand is discussed in greater detail below.

In reviewing the electric utility bills tor Hunter AAF, the total electric utility cost increased $10 \%$ during the first 6 months of 1993 over the first 6 months of 1992. During the same period, total electricity consumption for Hunter AAF increased $4.5 \%$ and billed demand did not change by any appreciable amount. The large cost increase coupled with a small consumption increase indicates a unit cost increase occurred.

Hunter AAF basic energy rates have slightly changed over the past 3 years. The demand and excess reactive power rates have not changed at all over the past 3 years. However, the fuel cost recovery factor has changed notably and is mainly responsible for the recent electric cost increase at Hunter AAF. Table 5.1 identifies the electric rates by component over the past 3 years. The incremental energy rate at Hunter AAF is illustrated in Figure 5.1 for the past 3 years. The incremental energy rate is defined as the cost of electricity for the last kilowatt-hour of energy. As shown in Figure 5.1, the fuel cost recovery rate decreased in May 1991 and again in October 1991. The rate then held constant for 14 months before increasing by over $20 \%$ in December 1992 . This increase in the fuel cost recovery rate coincided with the completion of the heat pump installation. 
Table 5.1. Electric Service Rates for Hunter AAF

\begin{tabular}{|c|c|c|c|c|c|c|}
\hline \multirow[b]{2}{*}{ Charge Component } & \multicolumn{2}{|c|}{ FY91 } & \multicolumn{2}{|c|}{ FY92 } & \multicolumn{2}{|c|}{ FY93 } \\
\hline & Off-Peak & On-Peak & Off-Peak & On-Peak & Off-Peak & On-Peak \\
\hline Facility Charge (\$/mo) & 100.00 & 100.00 & 100.00 & 100.00 & 100.00 & 100.00 \\
\hline Demand Charge ( $(\$ / k W m o)$ & 3.00 & 3.25 & 3.00 & 3.25 & 3.00 & 3.25 \\
\hline \multicolumn{7}{|l|}{ Energy Charge ( $\$ / \mathbf{k W h})$} \\
\hline Step 1 & 0.0500 & 0.0550 & 0.0500 & 0.0543 & 0.0493 & 0.0543 \\
\hline Step 2 & 0.0450 & 0.0500 & 0.0450 & 0.0493 & 0.0443 & 0.0493 \\
\hline Step 3 & 0.0250 & 0.0300 & 0.0250 & 0.0293 & 0.0243 & 0.0293 \\
\hline Step 4 & 0.0150 & 0.0210 & 0.0160 & 0.0202 & 0.0152 & 0.0293 \\
\hline Step 5 & 0.0120 & 0.0130 & 0.0120 & 0.0122 & 0.0112 & 0.0122 \\
\hline Fuel Cost Recovery ( $\$ / \mathrm{kWh})$ & 0.0245 & 0.0201 & 0.0182 & 0.0182 & 0.0219 & 0.0219 \\
\hline $\begin{array}{l}\text { Excess Reactive Power } \\
\text { Charge }(\$ / k V A R \cdot m o)\end{array}$ & 0.50 & 0.50 & 0.50 & 0.50 & 0.50 & 0.50 \\
\hline
\end{tabular}

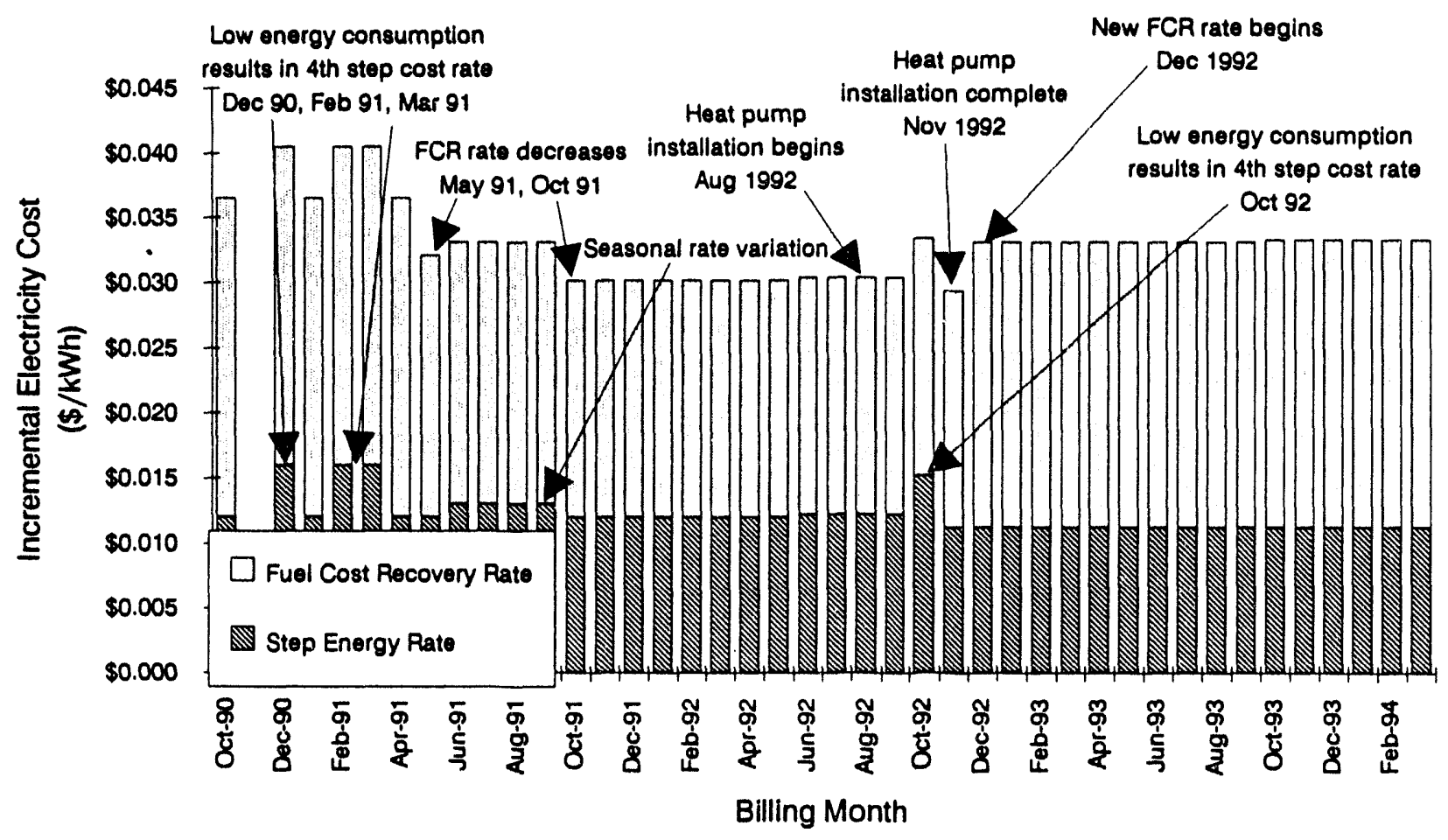

Figure 5.1. Electric Rate Analysis, Hunter AAF 
Although actual demand increased during the winter heating season, billed demand did not increase because Hunter AAF is usually ratcheted during the winter. Actual peak demand at Hunter AAF increased $5 \%$ in FY93 over FY92. However, billed demand increased less than $0.4 \%$ in FY93. This increase should be expected with the installation of the heat pumps; especially because Hunter AAF is usually subject to the ratchet clause for 6 to 7 months out of each year. Actual demand during the heating season increased, probably because of the installation of 482 supplemental resistance heaters rated at $7.5 \mathrm{~kW}$ each, for an increase in the connected load of $3,660 \mathrm{~kW}$. However, actual demand during the cooling season increased only slightly, probably because of an almost $10 \%$ increase in cooling degree-days, which were offset by the increase in the cooling efficiency of the heat pumps from a rated SEER of 7.4 to 10.0 (a $35 \%$ increase). Because Hunter AAF has been subject to the demand ratchet clause, most of the winter demand increase offset the ratchet. The billed demand during the winter season changed very little. The long-term effect for Hunter AAF is that summer demand is likely to be similar or slightly lower than before heat pump installation and winter demand is likely to be similar or slightly higher than before heat pump installation, and the ratchet clause may not bz applicable as often as before. 


\subsection{Verify and Identify Causes for Electricity Cost Increase}

To demonstrate the significance of the fuel cost recovery $(\mathrm{CR})$ rate increase, the monthly electricity costs for FY93 billing data, using the actual FY93 rate schedule, and the FY92 rate schedule are compared in Table 6.1. As shown in Table 5.1, there were slightly different off-peak rates in the declining blocks of FY92 and FY93, with lower rates in FY93. Thus, a negative difference is identified in Table 6.1 for the months of October and November 1992. The increase in the fuel cost recovery component, however, resulted in a significant increase in the total Hunter AAF electric bill.

The total Hunter AAF electric utility bill was $\$ 176,681$ higher in FY93 than in FY92--an increase of $8.3 \%$. The rate schedule changed in October 1992, which lowered off-peak electricity rates. The fuel cost recovery rate increased in December 1992, accounting for $74 \%$ of the total cost increase. Electric energy consumption at Hunter AAF increased 3\% in FY93 over FY92, accounting for 25\% of the cost increase. Although the heat pumps had some impact on this change in consumption, the change in the weather was more significant. Cooling degree-days for Savannah, Georgia, synchronized

Table 6.1. Hunter AAF Utility Rate Change Analysis - FY93

\begin{tabular}{|c|c|c|c|c|}
\hline $\begin{array}{l}\text { Billing } \\
\text { Month }\end{array}$ & $\begin{array}{l}\text { Actual Electricity } \\
\text { Cost FY93 }\end{array}$ & $\begin{array}{l}\text { Electricity Cost } \\
\text { Using FY92 Rate }\end{array}$ & Difference & Comment \\
\hline Oct 92 & $\$ 163,149.08$ & $\$ 165,782.96$ & $(\$ 2,633.88)$ & New rate schedule effective \\
\hline Nov 92 & $\$ 142,890.02$ & $\$ 145,358.14$ & $(\$ 2,468.12)$ & $\begin{array}{l}\text { Heat pump installation } \\
\text { complete }\end{array}$ \\
\hline Dec 92 & $\$ 168,480.20$ & $\$ 157,782.00$ & $\$ 10,698.20$ & CR rate increase effective \\
\hline $\operatorname{Jan} 93$ & $\$ 156,408.44$ & $\$ 146,687.60$ & $\$ 9,720.84$ & \\
\hline Feb 93 & $\$ 165,305.72$ & $\$ 154,805.36$ & $\$ 10,500.36$ & \\
\hline $\operatorname{Mar} 93$ & $\$ 158,554.22$ & $\$ 148,732.72$ & $\$ 9,821.50$ & \\
\hline Apr 93 & $\$ 148,994.04$ & $\$ 139,922.80$ & $\$ 9,071.24$ & \\
\hline May 93 & $\$ 174,427.32$ & $\$ 163,648.58$ & $\$ 10,778.74$ & \\
\hline Jun 93 & $\$ 242,283.28$ & $\$ 224,795.60$ & $\$ 17,487.68$ & \\
\hline Jul 93 & $\$ 278,954.82$ & $\$ 257,986.18$ & $\$ 20,968.64$ & \\
\hline Aug 93 & $\$ 249,277.20$ & $\$ 231,209.36$ & $\$ 18,067.84$ & \\
\hline Sep 93 & $\$ 245,327.56$ & $\$ 227,342.60$ & $\$ 17,984.96$ & \\
\hline Cotal FY93 & $\$ 2,294,051.90$ & $\$ 2,164,053.90$ & $\$ 129,998.00$ & \\
\hline
\end{tabular}


to the utility billing period, increased $9.8 \%$ in FY93 over FY92. Heating degree-days increased 3.8\% in FY93 over FY92. The impact of weather on the total electricity consumption at Hunter AAF is difficult to determine with any statistical certainty. However, a multivariate regression model, developed using billing data from 1991 and 1992, indicates the change in weather may account for a consumption increase of around $2.5 \%$ in FY93 over FY92. An it srease in billed demand and excess kVAR charges account for around $1 \%$ of the total cost increase. 


\subsection{Conclusions}

The results of the analysis on the change in electricity consumption at Hunter AAF resulting from installing heat pumps in family housing are not statistically conclusive. The result of the monthly regression model indicates that annual electricity consumption may have increased $3.3 \%$, or $266,926 \mathrm{kWh}$, at a cost increase of $\$ 7,490$ in 1993 over 1992, while the result of the 12-month floating window analysis indicates that annual electricity consumption may have decreased $2.6 \%$, or $224,100 \mathrm{kWh}$, at a cost reduction of $\$ 7,485$ in 1993 over 1992 . In both methods, however, the net annual change in consumption is well within the confidence interval and is not considered statistically significant. Therefore, there was no (statistically) significant change in annual electricity consumption resulting from the installation of the heat pumps.

The results of the analysis on the change in fuel oil consumption at Hunter AAF resulting from the installation of heat pumps in family housing is conclusive. However, because of the lack of data, a confidence interval cannot be identified. It is reasonable to conclude, however, that fuel oil consumption decreased $66,674 \mathrm{gal}(9,334.4 \mathrm{MBtu})$ in 1993 for a cost reduction of $\$ 46,672$.

The results of the field inspection of the heat pumps are inconclusive. However, there is an indication that the thermostat controls may not be properly installed. Therefore, PNL recommends that a qualified service technician trace and verify the wiring at the thermostat controls to the heat pump. The heat pumps should then be monitored at the beginning of the next heating season for proper operation and corrected if necessary. These tasks can be accomplished by on-site personnel.

The results of the analysis on the electric utility bills for Hunter AAF indicate the energy cost increase during FY93 can mostly be attributed to an increase in the fuel cost recovery rate component that took effect in December 1992. The weather, in the form of an increase in cooling degree-days and heating degree-days during 1993, was also responsible for a portion of the increase in the electric utility cost. 


\subsection{Reference}

National Institute of Standards and Technology (NIST). 1991. Energy Prices and Discount Factors for Life-Cycle Cost Analysis 1992. NIST Handbook 135, National Technical Information Service, Springfield, Virginia. 
Appendix A

Electric Submeter and Weather Data Hunter AAF Family Housing 
Electric Submeter and Weather Data for Family Housing at Hunter AAF

Officer's Quarter's

\begin{tabular}{|c|c|c|c|c|}
\hline \multirow{2}{*}{$\begin{array}{l}\text { Date } \\
\text { Meter } \\
\text { Read } \\
\end{array}$} & \multirow{2}{*}{$\begin{array}{c}\text { No. } \\
\text { of } \\
\text { Days }\end{array}$} & \multirow{2}{*}{$\begin{array}{c}\text { Elect. } \\
\text { Consum. } \\
(\mathrm{kWh})\end{array}$} & \multicolumn{2}{|c|}{ Degree - Days } \\
\hline & & & $\begin{array}{l}\text { Heating } \\
\left({ }^{\circ} \mathrm{F} \cdot \mathrm{d} / \mathrm{mo}\right)\end{array}$ & $\begin{array}{l}\text { Cooling } \\
\left({ }^{\circ} \mathrm{F} \cdot \mathrm{d} / \mathrm{mo}\right)\end{array}$ \\
\hline $11-$ Oct-90 & & 441,600 & $n / a$ & $n / a$ \\
\hline $11-$ Nov-90 & 31 & 345,600 & $n / a$ & $n / a$ \\
\hline 12-Dec-90 & 31 & 240,000 & $n / a$ & $n / a$ \\
\hline 12-Jan-91 & 31 & 297,600 & $n / a$ & $n / a$ \\
\hline 12-Feb-91 & 31 & 278,400 & 371 & 3 \\
\hline 11-Mar-91 & 27 & 249,600 & 238 & 27 \\
\hline 11-Apr-91 & 31 & 288,000 & .85 & 97 \\
\hline 12-May-91 & 31 & 393,600 & 6 & 251 \\
\hline 12-Jun-91 & 31 & 489,600 & 0 & 394 \\
\hline 15-Jul-91 & 33 & 595,200 & 0 & 598 \\
\hline 15-Aug-91 & 31 & 489,600 & 0 & 564 \\
\hline 15-Sep-91 & 31 & 528,000 & 0 & 493 \\
\hline $15-$ Oct-91 & 30 & 480,000 & 16 & 245 \\
\hline 15-Nov-91 & 31 & 240,000 & 193 & 69 \\
\hline 16-Dec-91 & 31 & 384,000 & 190 & 53 \\
\hline 15-Jan-92 & 30 & 393,600 & 389 & 0 \\
\hline 7-Feb-92 & 23 & 153,600 & 382 & 0 \\
\hline 10-Mar-92 & 32 & 172,800 & 192 & 36 \\
\hline 10-Apr-92 & 31 & 192,000 & 261 & 8 \\
\hline 8-May-92 & 28 & 96,000 & 49 & 126 \\
\hline 10-Jun-92 & 33 & 172,800 & 9 & 317 \\
\hline 10-Jul-92 & 30 & 499,200 & 0 & 461 \\
\hline 10-Aug-92 & 31 & 556,800 & 0 & 600 \\
\hline 10-Sep-92 & 31 & 576,000 & 0 & 474 \\
\hline 13-Oct-92 & 33 & 480,000 & 15 & 284 \\
\hline 13-Nov-92 & 31 & 576,000 & 89 & 92 \\
\hline 14-Dec-92 & 31 & 508,800 & 369 & 31 \\
\hline 14-Jan-93 & 31 & 518,400 & 245 & 19 \\
\hline 12-Feb-93 & 29 & 547,200 & 400 & 0 \\
\hline 10-Mar-93 & 26 & 384,000 & 346 & 0 \\
\hline 14-Apr-93 & 35 & 432,000 & 232 & 27 \\
\hline 11-May-93 & 27 & 115,200 & 48 & 115 \\
\hline 15-Jun-93 & 35 & 288,000 & 0 & 427 \\
\hline 15-Jul-93 & 30 & 412,800 & 0 & 549 \\
\hline 10-Aug-93 & 26 & 211,200 & 0 & 553 \\
\hline 10-Sep-93 & 31 & 316,800 & 0 & 552 \\
\hline 15-Oct-93 & 35 & 518,400 & 14 & 368 \\
\hline 18-Nov-93 & 34 & 345,600 & 157 & 108 \\
\hline 13-Dec-93 & 25 & 403,200 & 201 & 10 \\
\hline 18-Jan-94 & 36 & 355,200 & 626 & 0 \\
\hline 14-Feb-94 & 27 & 576,000 & $n / a$ & $n / a$ \\
\hline 14-Mar-94 & 28 & 412,800 & $n / a$ & $n / a$ \\
\hline
\end{tabular}

NCO's Quarters

\begin{tabular}{|c|c|c|c|c|}
\hline \multirow{2}{*}{$\begin{array}{l}\text { Date } \\
\text { Meter } \\
\text { Read }\end{array}$} & \multirow{2}{*}{$\begin{array}{c}\text { No. } \\
\text { of } \\
\text { Days }\end{array}$} & \multirow{2}{*}{$\begin{array}{c}\text { Elect. } \\
\text { Consum. } \\
\text { (kWh) }\end{array}$} & \multicolumn{2}{|c|}{ Degree - Days } \\
\hline & & & $\begin{array}{l}\text { Heating } \\
\left({ }^{\circ} \mathrm{F} \cdot \mathrm{d} / \mathrm{mo}\right)\end{array}$ & $\begin{array}{l}\text { Cooling } \\
\left.\text { ( }{ }^{\circ} \mathrm{F} \cdot \mathrm{d} / \mathrm{mo}\right)\end{array}$ \\
\hline $11-$ oct-90 & & 412,800 & $n / a$ & $n / a$ \\
\hline 13-Nov-90 & 33 & 499,200 & $n / a$ & $n / a$ \\
\hline 12-Dec-90 & 29 & 245,000 & $n / a$ & $n / a$ \\
\hline 12-Jan-91 & 31 & 240,000 & $n / a$ & $n / a$ \\
\hline 12-Fob-91 & 31 & 220,800 & 371 & 3 \\
\hline 11-Mar-91 & 27 & 211,200 & 238 & 27 \\
\hline 11-Apr-91 & 31 & 249,600 & 85 & 97 \\
\hline 12-May-91 & 31 & 355,200 & 6 & 251 \\
\hline 12-Jun-91 & 31 & 412,800 & 0 & 394 \\
\hline 15-Jul-91 & 33 & 518,400 & 0 & 598 \\
\hline 15-Aug-91 & 31 & 422,400 & 0 & 564 \\
\hline 15-Sep-91 & 31 & 460,800 & 0 & 493 \\
\hline 15-Oct-91 & 30 & 422,400 & 16 & 245 \\
\hline 15-Nov-91 & 31 & 211,200 & 193 & 69 \\
\hline 16-Dec-91 & 31 & 345,600 & 190 & 53 \\
\hline 15-Jan-92 & 30 & 249,600 & 389 & 0 \\
\hline 7-Feb-92 & 23 & 297,600 & 382 & 0 \\
\hline 10-Mar-92 & 32 & 278,400 & 192 & 36 \\
\hline 10-Apr-92 & 31 & 163,200 & 261 & 8 \\
\hline 8-May-92 & 28 & 268,800 & 49 & 126 \\
\hline 1C-Jun-92 & 33 & 374,400 & 9 & 317 \\
\hline 10-Jul-92 & 30 & 432,000 & 0 & 461 \\
\hline 10-Aug-92 & 31 & 441,600 & 0 & 600 \\
\hline 10-Sep-92 & 31 & 460,800 & 0 & 474 \\
\hline 13-Oct-92 & 33 & 460,800 & 15 & 284 \\
\hline 13-Nov-92 & 31 & 201,600 & 89 & 92 \\
\hline 14-Dec-92 & 31 & 336,000 & 369 & 31 \\
\hline 14-Jan-93 & 31 & 374,400 & 245 & 19 \\
\hline 12-Feb-93 & 29 & 403,200 & 400 & 0 \\
\hline 10-Mar-93 & 26 & 336,000 & 346 & 0 \\
\hline 14-Apr-93 & 35 & 384,000 & 232 & 27 \\
\hline 11-May-93 & 27 & 249,600 & 48 & 115 \\
\hline 15-Jun-93 & 35 & 307,200 & 0 & 427 \\
\hline 15-Jul-93 & 30 & 230,400 & 0 & 549 \\
\hline 11-Aug-93 & 27 & 249,600 & 0 & 568 \\
\hline 10-Sep-93 & 30 & 422,400 & 0 & 537 \\
\hline 15-Oct-93 & 35 & 345,600 & 14 & 368 \\
\hline 18-Nov-93 & 34 & 297,600 & 157 & 108 \\
\hline 13-Dec-93 & 25 & 345,600 & 201 & 10 \\
\hline 18-Jan-94 & 36 & 384,000 & 626 & 0 \\
\hline 14-Feb-94 & 27 & 652,800 & $n / a$ & $n / a$ \\
\hline 14-Mar-94 & 28 & 614,400 & $n / a$ & $n / a$ \\
\hline
\end{tabular}


Appendix B

\section{Fuel Oil Delivery and Weather Data}

Hunter AAF Family Housing 
Fuel Oil Delivery and Weather Data for Family Housing at Hunter AAF

\begin{tabular}{|c|c|c|c|}
\hline $\begin{array}{l}\text { Bllling } \\
\text { Month }\end{array}$ & $\begin{array}{l}\text { Fuel Oil } \\
\text { Delivery } \\
\text { (gal) }\end{array}$ & $\begin{array}{c}\text { Heating } \\
\text { Degree-Days } \\
\left({ }^{\circ} \mathrm{F} \cdot \mathrm{d} / \mathrm{mo}\right)\end{array}$ & Comments \\
\hline Oct-90 & 0 & 55 & \\
\hline Nov-90 & 306 & 143 & \\
\hline Dec-90 & 1,396 & 279 & \\
\hline Jan-91 & 3,314 & 395 & \\
\hline Fob-91 & 32,188 & 260 & \\
\hline Mar-91 & 379 & 139 & \\
\hline Apr-91 & 10,818 & 14 & \\
\hline May-91 & 2,885 & 0 & \\
\hline Jun-91 & 0 & 0 & \\
\hline Jul-91 & 0 & 0 & \\
\hline Aug-91 & 0 & 0 & \\
\hline Sep-91 & 0 & 0 & \\
\hline FY 91 & 51,286 & 1,285 & Average $39.9 \mathrm{gal} / \mathrm{HOD}$ \\
\hline Oct-91 & 7,227 & 34 & \\
\hline Nov-91 & 3,564 & 270 & \\
\hline Dec-91 & 5,537 & 315 & \\
\hline Jan-92 & 6,666 & 461 & \\
\hline Feb-92 & 19,565 & 274 & \\
\hline Mar-92 & 13,760 & 204 & \\
\hline Apr-92 & 1,418 & 101 & \\
\hline May-92 & 729 & 22 & \\
\hline Jun-92 & 0 & 0 & \\
\hline Jul-92 & 0 & 0 & \\
\hline Aug-92 & 0 & 0 & Heat pump installation begins \\
\hline Sep-92 & 0 & 1 & \\
\hline FY 92 & 58,466 & 1,682 & Average $34.8 \mathrm{gal} / \mathrm{HDD}$ \\
\hline Oct-92 & 15 & 45 & \\
\hline Nov-92 & 6,436 & 194 & Heat pump installation complete \\
\hline Dec-92 & 369 & 401 & \\
\hline Jan-93 & 0 & 320 & \\
\hline Feb-93 & 0 & 406 & \\
\hline Mar-93 & 0 & 254 & \\
\hline Apr-93 & 0 & 113 & \\
\hline May-93 & 0 & 0 & \\
\hline Jun-93 & 0 & 0 & \\
\hline Jul-93 & 0 & 0 & \\
\hline Aug-93 & 0 & 0 & \\
\hline Sep-93 & 0 & 1 & \\
\hline \multicolumn{4}{|l|}{ FY 93 } \\
\hline Oct-93 & 0 & 45 & \\
\hline Nov-93 & 0 & 193 & \\
\hline Dec-93 & 0 & 470 & \\
\hline Jan-94 & 0 & 530 & \\
\hline Feb-94 & 0 & $n / a$ & \\
\hline Mar-94 & 0 & $n / a$ & \\
\hline
\end{tabular}

B. 1 


\section{Appendix C}

\section{Monthly Regression Analysis Results}

Hunter AAF Family Housing 


\section{Monthly Regression Analysis Results for Hunter AAF Family Housing}

Regression Analysis Output: Officer's Family Housing

Regression Statistics

Multiple R

$78.00 \%$

R Square

$60.84 \%$

Adjusted R Square

$52.65 \%$

Standard Error

100,638

Observations

19

Analysis of Variance

\begin{tabular}{lrrrrr} 
& of & Sum of Squares & Mean Square & $F$ & Significance $F$ \\
\hline Regression & 2 & $2.67 E+11$ & $1.34 \mathrm{E}+11$ & 13.21 & $4.10 \mathrm{E}-04$ \\
Residual & 17 & $1.72 \mathrm{E}+11$ & $1.01 \mathrm{E}+10$ & & \\
Total & 19 & $4.40 \mathrm{E}+11$ & & &
\end{tabular}

\begin{tabular}{lrrrrrr} 
& Coefficients & Standard Error & t Statistic & P-value & Lower 95\% & Upper 95\% \\
\hline & & & & & & \\
Intercept & 0.00 & $n / a$ & $n / a$ & $n / a$ & $n / a$ & \multicolumn{1}{c}{$n / a$} \\
X1 (No. of days/mo) & $7,689.64$ & $1,128.85$ & 6.81 & $1.67 E-06$ & $5,307.96$ & $10,071.32$ \\
X2 (CDD/mo) & 510.61 & 108.36 & 4.71 & $1.52 \mathrm{E}-04$ & 281.99 & 739.24
\end{tabular}

Regression $\mathrm{kWh} / \mathrm{mo}=(7,689.64) *($ No. of days $/ \mathrm{mo})+(510.61)^{\star}($ Cooling degree-days $/ \mathrm{mo})$

C. 1 
Regression Analysis Output: NCO Family Housing

Regression Statistics

$\begin{array}{lr}\text { Multiple R } & 87.15 \% \\ \text { R Square } & 75.95 \% \\ \text { Adjusted R Square } & 68.66 \% \\ \text { Standard Error } & 51,893 \\ \text { Observations } & 19\end{array}$

\begin{tabular}{lrrrrr}
\multicolumn{1}{c}{ Analysis of Variance } & & & & \\
& of & Sum of Squares & Mean Square & $F$ & Significance $F$ \\
\hline Regression & 2 & $1.45 \mathrm{E}+11$ & $7.23 \mathrm{E}+10$ & 26.85 & $7.72 \mathrm{E}-06$ \\
Residual & 17 & $4.58 \mathrm{E}+10$ & $2.69 \mathrm{E}+09$ & & \\
Total & 19 & $1.90 \mathrm{E}+11$ & & &
\end{tabular}

\begin{tabular}{lrrrrrr} 
& Coefficients & Standard Error & t Statistic & P-va/ue & Lower 95\% & Upper 95\% \\
\hline & & & & & & \\
Intercept & 0.00 & $n / a$ & $n / a$ & $n / a$ & $n / a$ & \multicolumn{1}{c}{$n / a$} \\
X1 (No. of days/mo) & $8,046.15$ & 582.09 & 13.82 & $2.30 \mathrm{E}-11$ & $6,818.05$ & $9,274.25$ \\
X2 (CDD/mo) & 385.15 & 55.88 & 6.89 & $1.42 \mathrm{E}-06$ & 267.26 & 503.04
\end{tabular}

Regression $\mathrm{kWh} / \mathrm{mo}=(8,046.15)^{\star}(\mathrm{No}$. of days $/ \mathrm{mo})+(385.15)^{\star}($ Cooling degree-days $/ \mathrm{mo})$ 
Appendix D

12-Month Floating Window Regression Analysis Results Hunter AAF Family Housing 
12-month Floating Window Regression Analysis Results for Hunter AAF Family Housing

Regression Analysis Output: All Family Housing

Regression Statistics

Multiple R

$99.15 \%$

$R$ Square

$98.30 \%$

Adjusted R Square

$98.02 \%$

Standard Error

69,925

Observations

8

Analysis of Varianco

\begin{tabular}{lcrrrr} 
& of & Sum of Squares & Mean Square & $F$ & Significance $F$ \\
\hline Regression & 1 & $1.70 E+12$ & $1.70 E+12$ & 347.18 & $1.54 E-06$ \\
Residual & 6 & $2.93 E+10$ & $4.89 E+09$ & & \\
Total & 7 & $1.73 E+12$ & &
\end{tabular}

Coefficients

Standard Emor

t Statistic

P.value

Lower 95\%

Upper 95\%

Intercept

$1,086,531.61$

$391,483.00$

$2.78 \quad 2.75 \mathrm{E}-02$

$28,606.52$

x1 (CDD/yr)

$2,777.12$

149.04

$\begin{array}{lll}18.63 & 3.18 E-07 & 2,412.42\end{array}$

$2,044,456.69$

Regression $\mathrm{kWh} / \mathrm{yr}=(1,086,531.61)+(2,777.12) \star($ Cooling degree-days $/ \mathrm{yr})$

D. 1 
Appendix E

\section{Electric Utility Billing Data}

Hunter AAF 
Electric Utility Billing Data for Hunter AAF

\begin{tabular}{|c|c|c|c|c|c|c|c|c|c|c|c|}
\hline \multirow{3}{*}{$\begin{array}{l}\text { Billing } \\
\text { Month }\end{array}$} & \multirow{2}{*}{\multicolumn{2}{|c|}{ Bllling Period }} & \multirow{3}{*}{\begin{tabular}{|l|} 
Billing \\
Period \\
(Days)
\end{tabular}} & \multirow{3}{*}{$\begin{array}{c}\text { Electricity } \\
\text { Consumptio } \\
(\mathrm{kWh})\end{array}$} & \multirow{3}{*}{$\begin{array}{c}\text { Actual } \\
\text { Demand } \\
(\mathrm{kW})\end{array}$} & \multirow{3}{*}{$\begin{array}{c}\text { Billed } \\
\text { Demand } \\
\text { (kW) }\end{array}$} & \multirow{3}{*}{$\begin{array}{c}\text { Ratcheted } \\
\text { Demand } \\
(Y \text { or } N) \\
\end{array}$} & \multirow{3}{*}{$\begin{array}{c}\text { Excess } \\
\text { Reactive } \\
\text { (kVAR) }\end{array}$} & \multirow{3}{*}{$\begin{array}{l}\text { Billed } \\
\text { Amount } \\
(\$)\end{array}$} & \multicolumn{2}{|c|}{ Weather Data } \\
\hline & & & & & & & & & & \multirow{2}{*}{$\begin{array}{c}\text { HDD } \\
\left({ }^{\circ} \mathrm{F} \cdot \mathrm{d} / \mathrm{mo}\right)\end{array}$} & \multirow{2}{*}{$\begin{array}{c}\mathrm{CDD} \\
\left({ }^{\circ} \mathrm{F} \cdot \mathrm{d} / \mathrm{mo}\right)\end{array}$} \\
\hline & From & To & & & & & & & & & \\
\hline Oct-90 & 21-Sep & $22-00 t$ & 31 & $4,065,600$ & 8,467 & 8,467 & $N$ & 19 & $\$ 204,942.70$ & $n / a$ & $n / a$ \\
\hline Nov-90 & 22.0ct & 20-Nov & 29 & $2,710,400$ & $n / a$ & $n / a$ & $n / a$ & $n / a$ & $n / a$ & $n / a$ & $n / a$ \\
\hline Dec-90 & 20-Nov & 20-Dec & 30 & $2,688,000$ & 5,376 & 6,887 & $Y$ & 0 & $\$ 144,271.60$ & $n / a$ & $n / a$ \\
\hline Jan-91 & 20-Doc & 22Jan & 33 & $2,867,200$ & 4,908 & 6,887 & $Y$ & 0 & $\$ 151,079.60$ & $n / a$ & $n / a$ \\
\hline Fob-91 & 22Jan & 21-Fob & 30 & $2,699,200$ & 4,852 & 6,887 & Y & 0 & $\$ 144,725.20$ & 348 & 11 \\
\hline Mar-91 & 21.Fob & 22-Mar & 29 & $2,520,000$ & 4,623 & 6,887 & $\mathbf{Y}$ & 0 & $\$ 137,467.60$ & 203 & 23 \\
\hline Apr-91 & 22-Mar & 23-Apr & 32 & $3,124,800$ & 6,599 & 6,887 & $Y$ & 0 & $\$ 160,482.00$ & 18 & 157 \\
\hline May-91 & 23-Apr & 23-May & 30 & $4,099,200$ & 8,628 & 8,628 & $\mathbf{N}$ & 8 & $\$ 189,157.52$ & 1 & 321 \\
\hline Jun-91 & 23-May & 24Jun & 32 & $4,894,400$ & 9,395 & 9,395 & $N$ & 137 & $\$ 241,931.89$ & 0 & 473 \\
\hline Jul-91 & 24-Jun & 24Jul & 30 & $5,062,400$ & 9,959 & 9.959 & $\mathbf{N}$ & 0 & $\$ 252,077.19$ & 0 & 539 \\
\hline Aug-91 & 24Jul & 23-Aug & 30 & $5,118,400$ & 10,053 & 10,053 & $N$ & 79 & $\$ 254,745.79$ & 0 & 537 \\
\hline Sep-91 & 23-Aug & 24-Sep & 32 & $5,118,400$ & 9,408 & 9,408 & $\mathbf{N}$ & 91 & $\$ 249,430.54$ & 0 & 485 \\
\hline FY 91 & & & 368 & $44,968,000$ & & & & & & & \\
\hline Oct-91 & 24Sop & 23-Oct & 29 & $3,572,800$ & 8,534 & 8,534 & $N$ & 0 & $\$ 164,866.16$ & 30 & 140 \\
\hline Nov-91 & $23-0 \mathrm{ct}$ & 21-Nov & 29 & $3,236,800$ & 7,392 & 7,392 & $N$ & 67 & $\$ 147,443.66$ & 187 & 66 \\
\hline Dec-91 & 21-Nov & 23-Dec & 32 & $3,360,000$ & 6,129 & 7,037 & $\mathbf{Y}$ & 0 & $\$ 148,858.80$ & 294 & 42 \\
\hline Jan-92 & 23-Dec & 23-Jan & 31 & $3,180,800$ & 5,833 & 7,037 & $Y$ & 0 & $\$ 143,446.96$ & 452 & 0 \\
\hline Fob-92 & 23-Jan & 21-Fob & 29 & $3,080,000$ & 5.914 & 7,037 & $Y$ & 0 & $\$ 140,402.80$ & 348 & 1 \\
\hline Mar-92 & 21.Fob & 24Mar & 32 & $3,270,400$ & 5,658 & 7,037 & $Y$ & 0 & $\$ 146,152.88$ & 192 & 39 \\
\hline Apr-92 & 24-Mar & 23-Apr & 30 & $3,012,800$ & 6,048 & 7,037 & $Y$ & 0 & $\$ 138,373.36$ & 124 & 67 \\
\hline May-92 & 23-Apr & 22-May & 29 & $3,561,600$ & 8,145 & 8,145 & $\mathbf{N}$ & 0 & $\$ 162,038.32$ & 54 & 166 \\
\hline Jun-92 & 22-May & 23Jun & 32 & $4,648,000$ & 9,085 & 9,085 & $N$ & 0 & $\$ 218,782.15$ & 0 & 382 \\
\hline Jul-92 & 23-Jun & 24-Jul & 31 & $5,208,000$ & 9,677 & 9,677 & $N$ & 128 & $\$ 240,765.99$ & 0 & 566 \\
\hline Aug.92 & 24-Jul & 24-Aug & 31 & $5,252,800$ & 9,946 & 9,946 & $\mathbf{N}$ & 0 & $\$ 244,288.54$ & 0 & 548 \\
\hline Sep-92 & 24Aug & 23-Sep & 30 & $4,726,400$ & 9,180 & 9,180 & $\mathrm{~N}$ & 0 & $\$ 221,951.16$ & 0 & 426 \\
\hline FY 92 & & & 365 & $46,110,400$ & 91,541 & 97,144 & & 195 & $\$ 2,117,370.78$ & 1,681 & 2,443 \\
\hline Oct-92 & 23-Sep & 22.0 ct & 29 & $3,516,800$ & 8,978 & 8,978 & $N$ & 128 & $\$ 163,149.08$ & 37 & 132 \\
\hline Nov-92 & 22-Oct & 20-Nov & 29 & $3,259,200$ & 6,828 & 6,962 & $Y$ & 47 & $\$ 142,890.02$ & 139 & 71 \\
\hline Doc-92 & 20-Nov & 22-Dec & 32 & $3,640,000$ & 7,110 & 7,110 & $N$ & 0 & $\$ 168,480.20$ & 360 & 35 \\
\hline Jan-93 & 22-Dec & 22-Jan & 31 & $3,304,000$ & 6,371 & 6,962 & $Y$ & 0 & $\$ 156,408.44$ & 283 & 15 \\
\hline Feb-93 & 22-Jan & 22-Fob & 31 & $3,572,800$ & 6,962 & 6,962 & $N$ & 0 & $\$ 165,305.72$ & 449 & 0 \\
\hline Mar-93 & 22-Fob & 24-Mar & 30 & $3,337,600$ & 7,123 & 7,123 & $N$ & 0 & $\$ 158,554.22$ & 351 & 3 \\
\hline Apr-93 & 24-Mar & 23-Apr & 30 & $3,080,000$ & 6,263 & 6,962 & $Y$ & 0 & $\$ 148,994.04$ & 104 & 38 \\
\hline May-93 & 23-Apr & 24-May & 31 & $3,662,400$ & 7,889 & 7,889 & $N$ & 409 & $\$ 174,427.32$ & 21 & 201 \\
\hline Jun-93 & 24-May & 23-Jun & 30 & $4,726,400$ & 9,502 & 9,502 & $N$ & 363 & $\$ 242,283.28$ & 0 & 442 \\
\hline Jul-93 & 23-Jun & 26-Jul & 33 & $5,667,200$ & 10,040 & 10,040 & $N$ & 645 & $\$ 278,954.82$ & 0 & 684 \\
\hline Aug.93 & 26-Jul & 24-Aug & 29 & $4,883,200$ & 9,704 & 9,704 & $N$ & 316 & $\$ 249,277.20$ & 0 & 570 \\
\hline Sep-93 & 24-Aug & 23-Sep. & 30 & $4,860,800$ & 9,314 & 9,314 & $\mathrm{~N}$ & 395 & $\$ 245,327.56$ & 0 & 491 \\
\hline FY 93 & & & 365 & $47,510,400$ & 96,084 & 97,508 & & 2,303 & $\$ 2,294,051.90$ & 1,744 & 2,682 \\
\hline Oct.93 & 23-Sep & 22-Oct & 29 & $3,864,000$ & 8,763 & 8,763 & $N$ & 321 & $\$ 187,246.96$ & 14 & 225 \\
\hline Nov-93 & $22.0 \mathrm{ct}$ & 22-Nov & 31 & $3,494,400$ & 6,908 & 7,028 & $Y$ & 263 & $\$ 163,790.06$ & 173 & 53 \\
\hline Dec-93 & 22-Nov & $22.00 \mathrm{C}$ & 30 & $3,393,600$ & 6,922 & 7,028 & $Y$ & 0 & $\$ 160,306.96$ & 321 & 2 \\
\hline Jan-94 & 22-Dec & 24-Jan & 33 & $4,043,200$ & 8,198 & 9,198 & $N$ & 0 & $\$ 189,417.56$ & 650 & 0 \\
\hline Feb-94 & 24-Jan & 22-Feb & 29 & $3,404,800$ & 7,540 & 7,540 & $N$ & 0 & $\$ 163,966.40$ & $n / a$ & $n / a$ \\
\hline Mar-94 & 22-Fob & 23-Mar & 29 & $3,214,400$ & 6,330 & 7,028 & $Y$ & 0 & $\$ 154,348.56$ & $n / a$ & $n / a$ \\
\hline Apr-94 & 23-Mar & 22-Apr & 30 & $3,360,000$ & 7,338 & 7,338 & $N$ & 242 & $\$ 161,300.96$ & $n / a$ & $n / a$ \\
\hline
\end{tabular}




\section{Distribution}

No. of

Copies

Offsite

12 DOE/Office of Scientific and Technical Information

2 K. Dean Devine

Federal Energy Management Program

U.S. Department of Energy

EE-44

1000 Independence Avenue SW

Washington, DC 20585

M. Ginsberg

Federal Energy Management Program

U.S. Department of Energy

EE-44

1000 Independence Avenue SW

Washington, DC 20585

2 L. Harris

Federal Energy Management Program

U.S. Department of Energy

EE-44

1000 Independence Avenue SW

Washington, DC 20585

V. Petrolati

DOE/In-House Energy Management

U.S. Department of Energy

1000 Independence Avenue SW

Washington, DC 20585

A. Gillespie

Attn: FCEN-PWO

Bldg. 200

Fort McPherson, GA 30330-6000
No. of

Copies

Offsite

G. Hixson

Engineering and Housing

AFZP-DPW

Hunter Army Air Field, GA 31409-5026

R. Jones

Code AFZP-DEV

Building 1139

Fort Stewart, GA 31314-5000

V. Maulden

Engineering Services and Project Division AFZP-DEE

DPW

Fort Stewart, GA 31314

D. Salter

Code AFZP-DER-B

Building 1101

Fort Stewart, GA 31314

B. Starling

U.S. Army Corps of Engineers

Huntsville Division

CEHND-PM-CR

P.O. Box 1600

Huntsville, AL $35807-4301$

B. Thomas

Building 1024

Hunter Army Air Field, GA 31409

B. Wargo

Hunter Army Air Field

Director of Energy \& Housing Facility

Energy Division

AFZP-DEF

Hunter Army Air Field, GA 31409-5026 
Onsite

DOE Richland Operations Office
D. D. Green
K8-50

19 Pacific Northwest Laboratory

$\begin{array}{ll}\text { C. A. Anderson } & \text { K5-20 } \\ \text { R. Bartlett } & \text { K8-15 } \\ \text { D. R. Dixon (2) } & \text { K8-17 } \\ \text { L. L. Larson } & \text { K8-17 } \\ \text { G. B. Parker } & \text { K7-82 } \\ \text { S. A. Parker (5) } & \text { K5-08 } \\ \text { W. F. Sandusky } & \text { K5-06 } \\ \text { G. P. Sullivan } & \text { K8-18 } \\ \text { Publishing Coordination } & \text { K1-06 } \\ \text { Technical Report Files (5) } & \text { P8-55 }\end{array}$

Distr. 2 

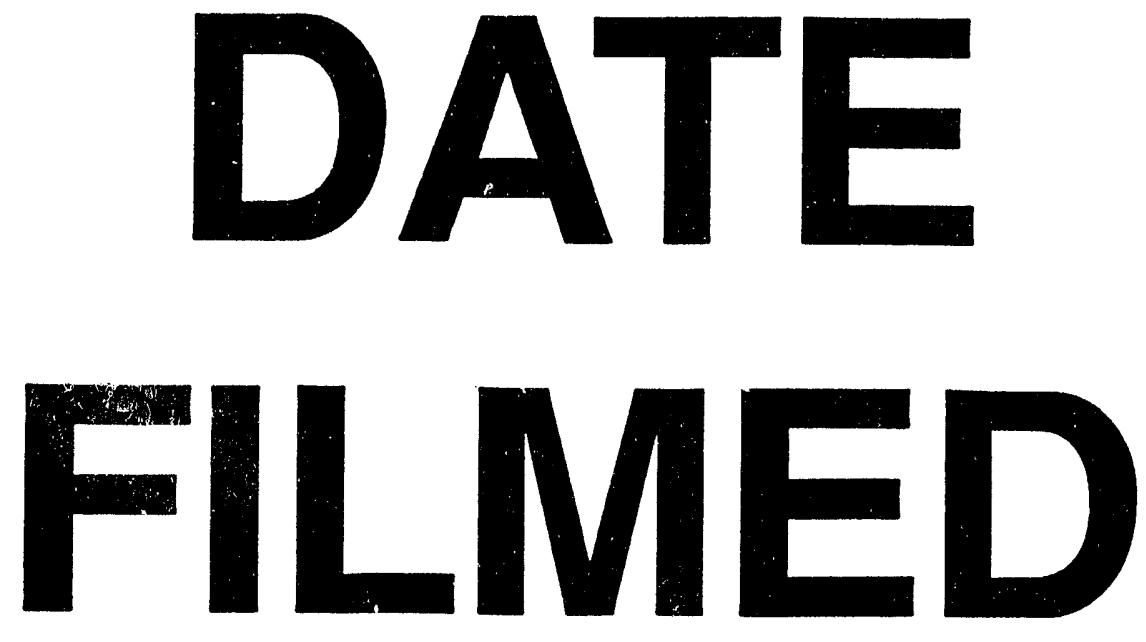

$10 / 18 / 94$
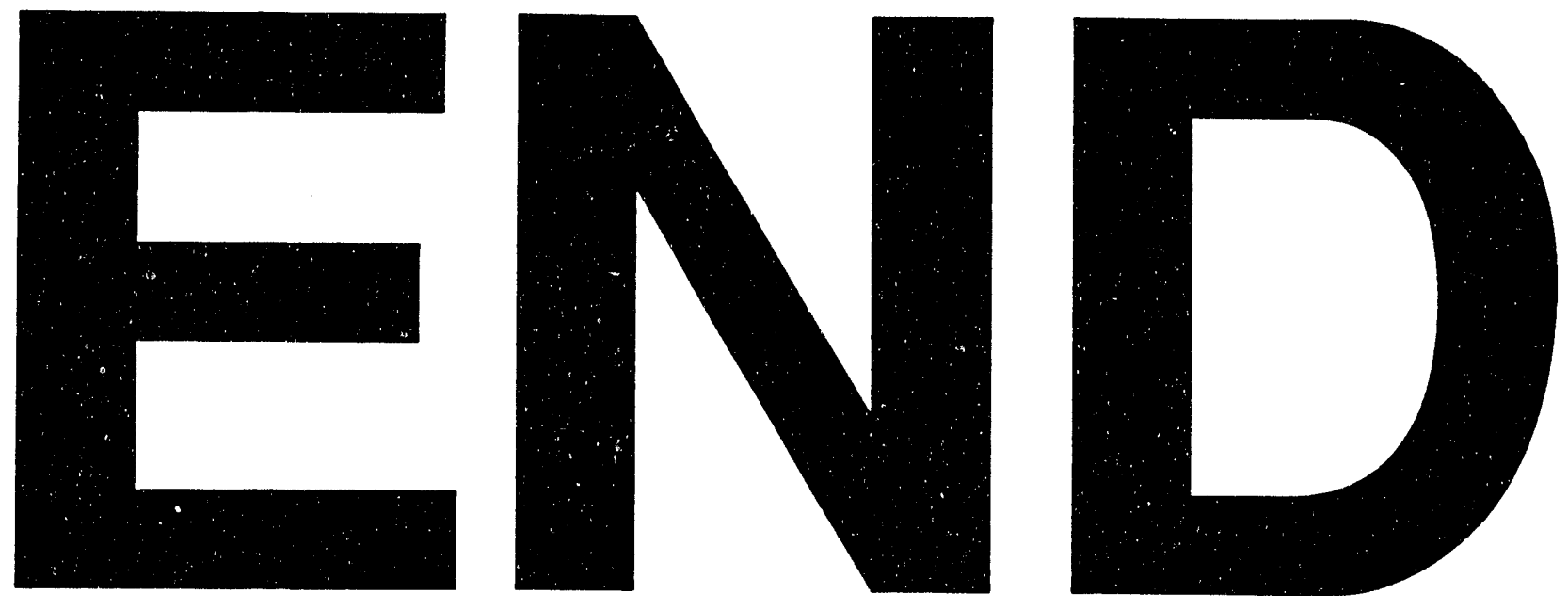
